\title{
Higher order chromatin degradation induced by hydrogen peroxide in glial cells
}

\author{
Raymond Mouzannar \\ West Virginia University
}

Follow this and additional works at: https://researchrepository.wvu.edu/etd

\section{Recommended Citation}

Mouzannar, Raymond, "Higher order chromatin degradation induced by hydrogen peroxide in glial cells" (2001). Graduate Theses, Dissertations, and Problem Reports. 1457.

https://researchrepository.wvu.edu/etd/1457

This Dissertation is protected by copyright and/or related rights. It has been brought to you by the The Research Repository @ WVU with permission from the rights-holder(s). You are free to use this Dissertation in any way that is permitted by the copyright and related rights legislation that applies to your use. For other uses you must obtain permission from the rights-holder(s) directly, unless additional rights are indicated by a Creative Commons license in the record and/ or on the work itself. This Dissertation has been accepted for inclusion in WVU Graduate Theses, Dissertations, and Problem Reports collection by an authorized administrator of The Research Repository @ WVU.

For more information, please contact researchrepository@mail.wvu.edu. 


\title{
Higher Order Chromatin Degradation Induced by Hydrogen Peroxide in Glial Cells
}

\author{
Raymond Mouzannar
}

Dissertation submitted to

the College of Agriculture

Forestry \& Consumer Sciences

at

West Virginia University

in partial fulfillment of the requirements

for the degree of

Doctor of Philosophy

in

Genetics and Developmental Biology

Interdisciplinary program of Genetics and Developmental Biology

Gregory W. Konat, Ph.D., Chair

Joginder Nath, Ph.D.

Walter Kaczmarczyk, Ph.D.

Richard C. Wiggins, Ph.D.

William A. Beresford, Ph.D.

Morgantown, West Virginia

2001

Keywords: Higher order chromatin digestion, programmed cell death, hydrogen peroxide, calcium, magnesium, oligodendrocytes, agarose embedding, field inversion gel electrophoresis 


\title{
ABSTRACT \\ Higher Order Chromatin Degradation Induced by Hydrogen \\ Peroxide in Glial Cells
}

\author{
Raymond Mouzannar
}

This study addresses the genotoxicity of oxidative stress. We induced oxidative stress in cultured rat oligodendrocytes by exposure to hydrogen peroxide $\left(\mathrm{H}_{2} \mathrm{O}_{2}\right)$. Intact genomic DNA was isolated by agarose embedding and its fragmentation was assessed by field inversion gel electrophoresis (FIGE). To detect single strand fragmentations, the DNA was digested with S1 nuclease before FIGE. We found that the exposure of oligodendrocytes to pathological concentrations of $\mathrm{H}_{2} \mathrm{O}_{2}$, induces a rapid digestion of nuclear chromatin in a pattern consistent with higher order chromatin degradation (HOCD). HOCD, the hallmark of programmed cell death (PCD), proceeds through single strand scissions that accumulate at matrix attachment regions (MAR). Within 10 min of the addition of $1 \mathrm{mM} \mathrm{H}_{2} \mathrm{O}_{2}$, a discrete pool representing approximately $45 \%$ of oligodendrocyte chromatin underwent single strand digestion into $\geq 400 \mathrm{~kb}$ fragments. Subsequently, chromatin was digested into 50-200kb fragments. Detectable chromatin digestion could be elicited with $\mathrm{H}_{2} \mathrm{O}_{2}$ concentrations as low as $50 \mu \mathrm{M}$. Chelating intracellular calcium with 1,2-bis (o-aminophenoxy)ethane-N,N,N',N'tetraacetic acid tetra(acetoxymethyl) ester (BAPTA/AM) prior to $\mathrm{H}_{2} \mathrm{O}_{2}$ exposure inhibited HOCD in a dose dependent manner. However, neither removing extracellular calcium, nor blocking calcium release from mitochondria and endoplasmic reticulum with 8-(N,Ndiethylamino)-ocyl-3,4,5-trimethoxybenzoate (TMB-8) affected the digestion. Moreover, increasing intracellular calcium with A23187 calcium ionophore did not induce HOCD. These results indicate that HOCD is not directly mediated by calcium, but resting level of calcium is required for the process. Subsequent study in nuclei purified from C6 glioma cells revealed that the endonuclease responsible for digestion is calcium-independent, but magnesium-dependent. Magnesium-induced HOCD was not affected by the removal of calcium from nuclei with ethylene glycol-bis( $\beta$-aminoethyl ether)-N,N,N',N'-tetraacetic acid (EGTA), but was practically inhibited in nuclei prepared from BABTA/AM-pretreated cells. In conclusion, although $\mathrm{H}_{2} \mathrm{O}_{2}$-induced $\mathrm{HOCD}$ is not directly mediated by the increase of intracellular calcium concentration, normal resting levels of intracellular calcium are required for the maintenance of MAR-associated, magnesium-dependent endonuclease in an active form. HOCD induced by oxidative stress may be an important mutagenic factor leading to cellular transformation via somatic mutations. 


\section{ACKNOWLEDGEMENTS}

I would like to thank Professor Joginder Nath, for giving me the opportunity to be here, and with the aid of the Anatomy department, help me earn a degree in what I long thought is a fascinating area in biology. I want to express my deepest gratitude to Professor Gregory W. Konat for his boundless wisdom, perpetual guidance, and amazing patience throughout this odyssey.

I would like to extend my gratitude to my dissertation committee members; Professor Joginder Nath, Professor Walter Kaczmarczyk, Professor Richard Wiggins, Professor William Beresford, for their invaluable contributions, insight and above all patience, which made this scrupulous journey possible.

I want to wholeheartedly thank everyone who was around and helped me directly or indirectly learn and enjoy science and life, genuinely, Professor Dennis Overman who I consider myself fortunate I met, to say the least.

My greatest thanks to my family who never lost hope in living an altruistic life during the most brutal times of our lives. To my parents Jacques \& Aida, I wholeheartedly thank you for your attention to education and dedication to your family. To my dear brother Joe, I revere the time you dedicated to me and our family. To my artful and beloved sister Pascale, thank you for always supporting your little brother. To my invigorating and sympathetic brother, Salim, this just simply could not be possible without you; I thank you with all my heart.

I am compelled to express my deepest thoughts to my family: Ranwa, Tara, Namir, Raya, Grace, Aunt Nana, Jean-Marie, Karine, Nakhle, Sheryl, and friends, 
Hisham Barakat, Issam Nassif, Heidi Nicoll, Mazen \& Malek Turk, Anas Khreiss, Sheryl Smith and Barbara Grubinska for their encouragement and support.

This dissertation is dedicated to Professor Simon Azoury who has been years of inspiration and influence on me. 


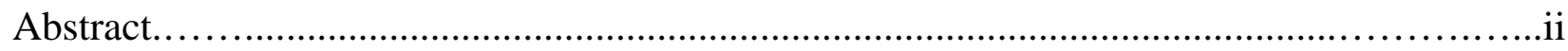

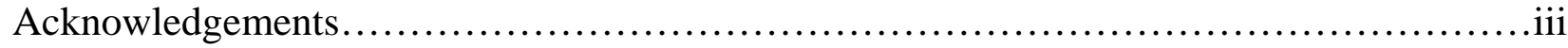

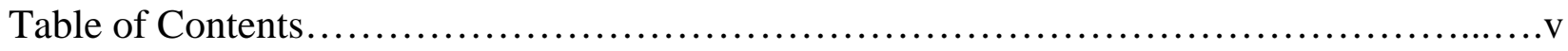

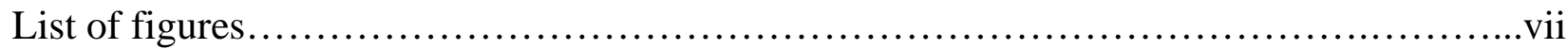

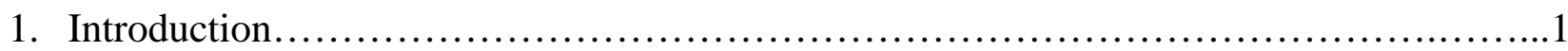

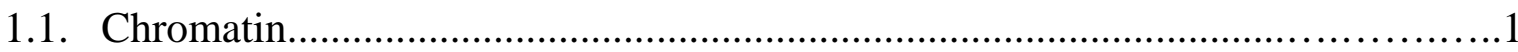

1.2. Chromatin Fragmentation and Programmed Cell Death (PCD)..................6

1.2.1 Endonucleases...................................................

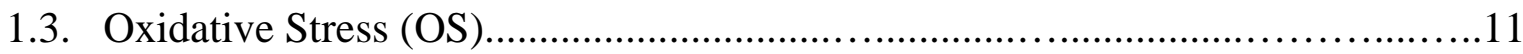

1.3.1. Reactive Oxygen Species (ROS)..........................................................11

1.3.2. Cellular Defense Mechanisms Against ROS.................................13

1.3.2.a. Enzymatic defense mechanisms.................................................14

1.3.2.b. Non-enzymatic defense mechanisms........................14

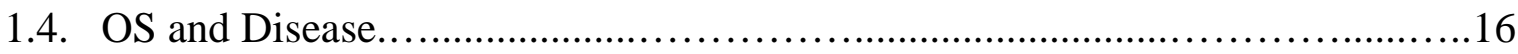

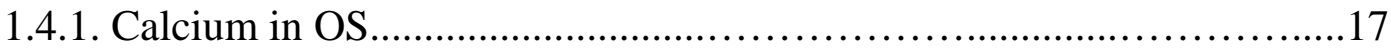

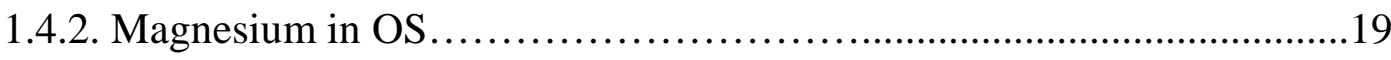

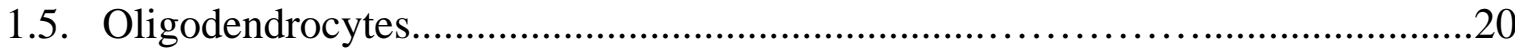

1.6. C6 cells as a model of Oligodendrocytes...............................22

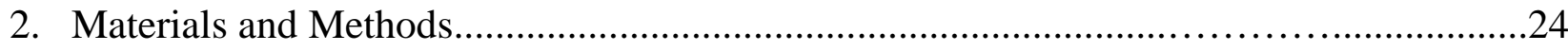

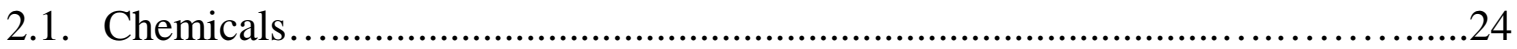

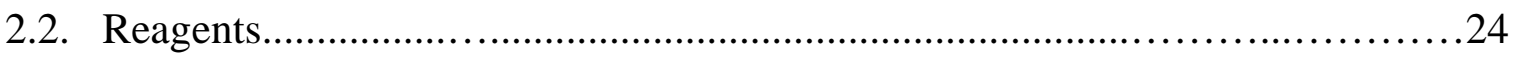

2.3. Calcium and iron reagents................................................. 25

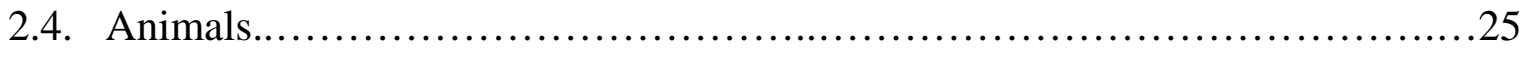

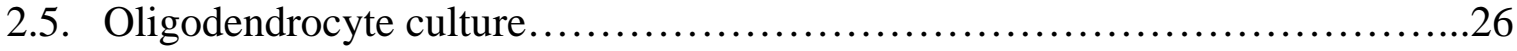

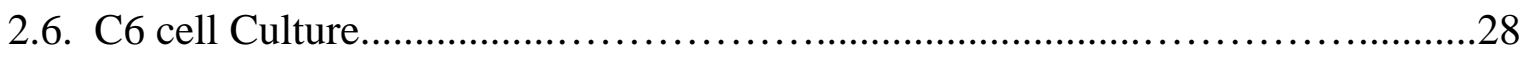

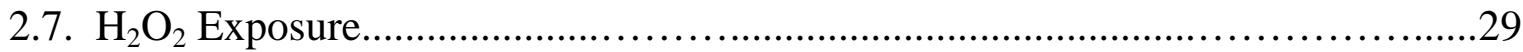

2.8. Agarose embedding \& DNA purification....................................29 
2.9. S1 Nuclease Digestion..................................................................................

2.10. Field Inversion Gel Electrophoresis (FIGE) ……...................................... 31

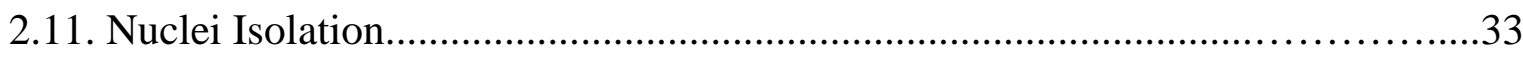

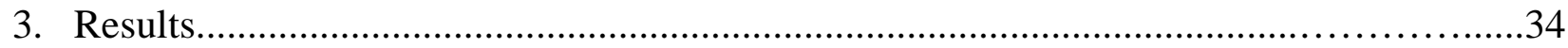

3.1. Kinetics and extent of chromatin fragmentation.........................................34

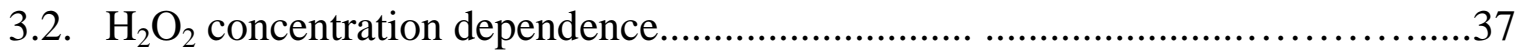

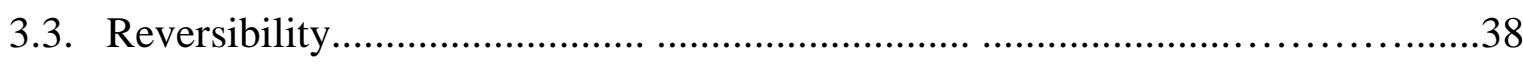

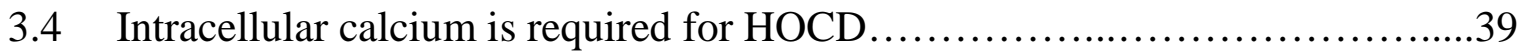

3.5. HOCD is not induced by intracellular calcium increase.............................42

3.6. MAR-associated endonuclease is calcium-independent but $\mathrm{Mg}$-dependent......43

3.7. Intracellular calcium depletion inactivates MAR-associated endonuclease.........48

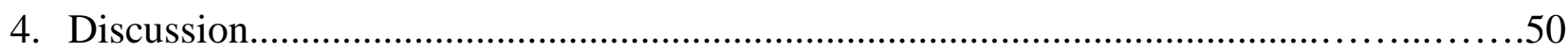

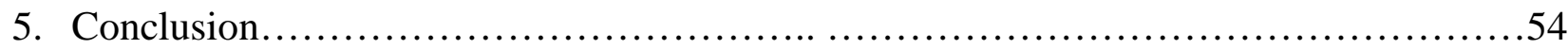

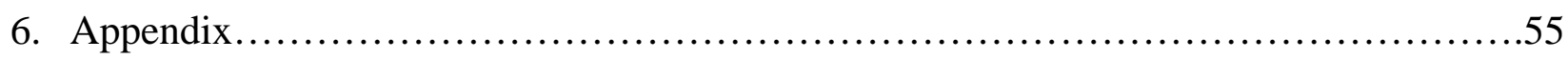

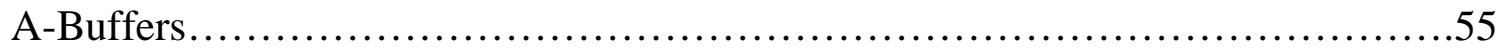

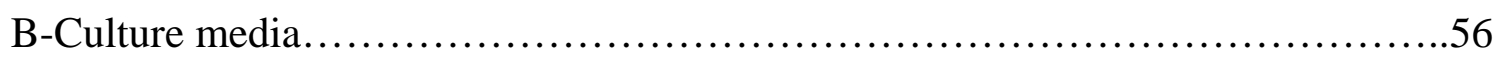

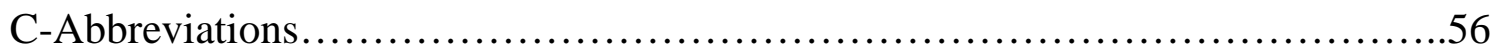

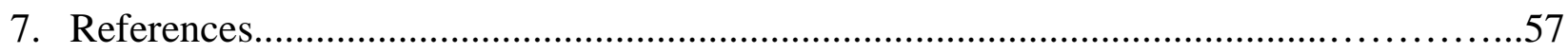




\section{LIST OF FIGURES}

Figure 1: Electron micrograph of 10 and $30 \mathrm{~nm}$ fibers.( Mol Biol Cell, $3^{\text {rd }}$ Ed.).

Figure 2: Light micrograph of lampbrush chromosome in amphibian oocyte (Mol Biol Cell, $3^{\text {rd }}$ Ed.).

Figure 3: Proposed model of the higher order chromatin folding in chromosomes (Filipski et al., 1990).

Figure 4: Proposed model of spatiotemporal digestion of chromatin during programmed cell death.

Figure 5: Delayed oligodendrocyte death following a brief exposure to $4 \mathrm{mM}$ hydrogen peroxide.

Figure 6: Schematic diagram of low melting point agarose embedding method.

Figure 7: Rapid degradation of OL chromatin induced by $\mathrm{H}_{2} \mathrm{O}_{2}$.

Figure 8: Fragmentation of OL chromatin induced by various $\mathrm{H}_{2} \mathrm{O}_{2}$ concentrations.

Figure 9: Transient decrease in $400 \mathrm{~kb}$ fragments during recovery of $\mathrm{H}_{2} \mathrm{O}_{2}$-treated OL.

Figure 10: The inhibition of $\mathrm{H}_{2} \mathrm{O}_{2}$-induced $\mathrm{HOCD}$ in cultured oligodendrocytes by BAPTA/AM.

Figure 11: The inhibition of $\mathrm{H}_{2} \mathrm{O}_{2}$-induced HOCD in cultured oligodendrocytes by DFOM.

Figure 12: The effects of extracellular calcium, TMB-8, and A23187 ionophore on HOCD in cultured oligodendrocytes.

Figure 13: Rapid degradation of C6 cells chromatin induced by $\mathrm{H}_{2} \mathrm{O}_{2}$.

Figure 14: The inhibition of $\mathrm{H}_{2} \mathrm{O}_{2}$-induced HOCD in C6 cells by BAPTA/AM.

Figure 15: The inhibition of $\mathrm{H}_{2} \mathrm{O}_{2}$-induced HOCD in C6 cells by DFOM.

Figure 16: The effect of $\mathrm{H}_{2} \mathrm{O}_{2}$ on chromatin digestion in purified nuclei.

Figure 17: The effect of calcium and magnesium on chromatin digestion in purified nuclei. 
Figure 18: Time course of magnesium-induced chromatin digestion in purified nuclei.

Figure 19: The effect of BABTA/AM pretreatment on magnesium-induced HOCD in C6 cells nuclei.

Figure 20: The effect of EGTA on magnesium-induced chromatin digestion in C6 cell nuclei. 


\section{INTRODUCTION}

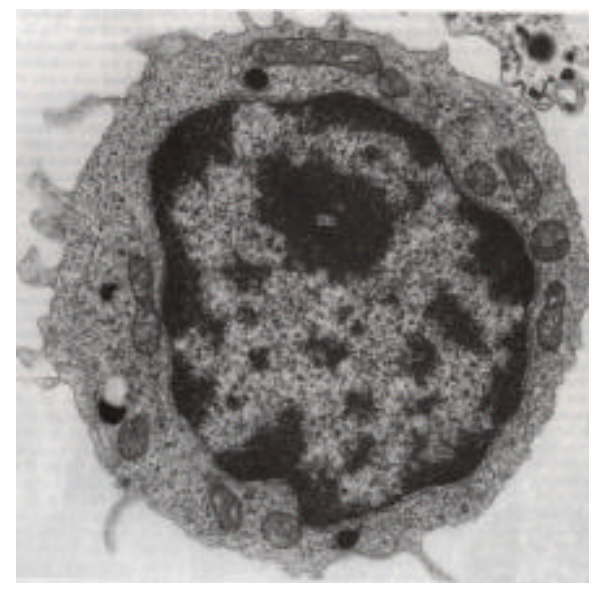

\subsection{Chromatin}

Chromatin organization is the fundamental key to understanding not only heredity, but also the harmonious interplay of genes that define the different phenotypes of cells in development and in response to environmental signals. DNA molecules present in eukaryotic cells are orderly and dynamically packaged by specific proteins to form chromatin. Hence, with the aid of histones, high mobility group (HMG) family of proteins, and ribonucleoproteins, double helical DNA is compacted by a factor of 10,000 to form the compact metaphase chromosome that is observed under the light microsocope. The mechanism of this packaging and its dynamics is a challenge, currently being resolved using X-ray diffraction, microscopy, and molecular biology techniques. In 1953, with the aid of Xray diffraction, Robert Watson and Francis Crick unraveled the double helical structure of DNA. Almost two decades later, R. Williamson observed a pattern of repeating unit fragments (200 base pairs monomers) generated by cultured embryonic mouse liver cells that were not growing well. Even though at that time chromatin was known to be structurally made of DNA and proteins, Williamson reasoned that the fragments were the result of 
incomplete synthesis of long DNA molecules which others had previously shown (Williamson, R, 1970). In 1973, Hewish and Burgoyne determined, by activating endogenous nuclease(s) in isolated liver nuclei, that the repeating pattern observed by Williamson consists of nucleoproteins monomers. They called the monomers: nucleosomes. Nucleosomes consisted of approximately 200 base pairs of DNA wrapped around what Kornberg has discovered in 1974, a histone octamer. This was the first link between non-random fragmentation of DNA and chromatin structure.

A flurry of research followed these discoveries. By using electron microscopy, X-ray diffraction and enzyme-digestion methods, it was shown that the 200 base pairs of DNA are arranged in the following manner: 168 base pairs are wrapped almost twice around the core histone particles into a shallow, left-handed supercoil. Approximately 50 base pairs make the link between one nucleosome and the next, hence, the $10 \mathrm{~nm}$ beads on a string structure observed (Olins and Olins, 1974; Richmond et al., 1984; Finch et al., 1977; Laskey et al., 1977; Lutter L.C., 1978). At this packaging stage, DNA is reduced in length by a factor of 6 . The $10 \mathrm{~nm}$ fiber does not resolve the packing problem of DNA and therefore a higher order of packaging must exist in eukaryotic interphase nuclei. Electron microscopy revealed a $30 \mathrm{~nm}$ fiber consisting of individual nucleosomes wrapped into a compact spiral, advancing $10 \mathrm{~nm}$ per turn (Thoma et al., 1979). Histone H1 protein and other non-histone HMG proteins were found to bind to the linker region of nucleosomes. H1 is the least conserved among histone proteins and $\mathrm{H} 5$ is one of its variants. Linker histones stabilize the $30 \mathrm{~nm}$ compact structure in vitro by binding through their globular domains and termini to linker and core DNA. (Allan et al., 1980; Leuba et al., 1994, Bustin and Reeves, 1996; Zlatanova and van Holde, 1998; An et al., 1988a; An et al., 1988b). Linker histones have been shown to fix the length of the DNA 
that is wrapped around the histone octamer without changing the linking number of the DNA associated with the nucleosome (Bednar et al., 1998). In addition, atomic force microscopy measurements, which has a resolution of $30 \mathrm{~nm}$ showed that linker histones are involved in fixing the angle between the incoming and outgoing DNA linkers. Hence, the apparent path of the nucleosomes in the $30 \mathrm{~nm}$ fiber is a zigzag trajectory whereby the incoming and outgoing linker DNAs do not cross. Accordingly, several models of linker histone binding to the chromatosome have been suggested. In vitro analysis of chromatin proved that, in the absence of $\mathrm{H} 1$ histone, DNA attached to the core particle assumes the "beads on a string" structure and

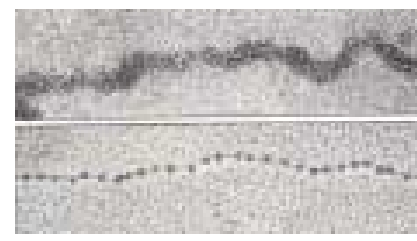

Figure 1.10 and $30 \mathrm{~nm}$ chromatin fibers. Electron micrographs showing chromatin strands before (top) and after (bottom) treatments that unpack, or 'decondense", the native structure to produce the beads on a string form. Mol Biol Cell. $3^{\text {rd }}$ ed.

has the tendency to unwrap (fig.1), a feature important for access of the transcription and replication machinery. It must be pointed out that the relevance of these structures to in vivo situations remains to be established. An additional six-fold packing ratio is obtained by such a structure making the DNA, together with the previous folding, almost 40 times shorter. Lamin intermediary filaments and their associated proteins are also involved in the physical structure of chromatin at the nuclear periphery. Indeed, lamin phosphorylation is an important feature for disintegration of the nucleus before mitosis or meiosis (Laskey RA, 1983) and lamin proteolysis was also linked to fragmentation of chromatin during programmed cell death (Earnshaw WC, 1995; Weaver, VM et al., 1996). However, details of the interaction of lamins with DNA are presently unknown. Because the $30 \mathrm{~nm}$ fiber has to be compacted by a ratio of 250 to form the compact chromosome seen in metaphase, it is reasonable to suggest that a higher order of chromatin structure exists between these two forms. 
The major evidence for this intermediate structure came from polytene chromosomes found in Drosophila salivary gland cells. Polytene chromosomes are giant chromosomes emanating from one thousand and twenty four copies of a single chromosome whereby each copy remains attached adjacently to its sister chromatid. The most striking feature of polytene chromosomes is the dark bands that are intercalated between light interbands. The dark bands contain $95 \%$ of chromatin, while the interbands comprise $5 \%$. Because the size of the two bands is the same, DNA must be more tightly packed in the bands than in the interbands. This provides some of the clearest evidence concerning the structural organization of a chromosome between the level of $30 \mathrm{~nm}$ fiber and that of the final, compact form which is seen only when a cell divides. Another structural feature observed in chromosomes is the loop structure found in lampbrush chromosomes of the frog or newt cells oocytes (fig.2). These are readily visible by the use of either a light or electron microscope for one simple reason: the genes along the loops are actively transcribed producing huge amounts of RNA, in preparation for making a new egg. Loops, 50 to $100 \mathrm{~kb}$ in size, are anchored to a proteinaceous matrix providing a firm support at one end and flexibility on the other. There are neither certain biochemical data to date showing a consensus DNA sequence that associates with the matrix, nor

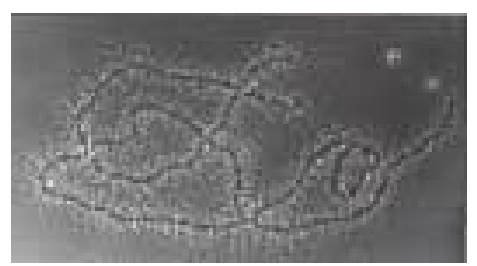

Figure 2. Light micrograph of lampbrush chromosome in an amphibian oocyte. Loops coated with RNA-protein complexes emanating from a linear chromosomal axis. Mol Biol Cell $3^{\text {rd }}$ Ed. data of composition of the proteinaceous matrix. However, the DNA joining the matrix, termed matrix attachment region (MAR) or scaffold attachment region (SAR) is rich in AT sequences of less than $200 \mathrm{bp}$ and has the tendency to unwrap under superhelical stress (Kohwi-Shigematsu and Kowhi, 1990). It seems possible that the bands and interbands seen in polytene chromosomes are constructed from a series of such loops. Each loop would 
compact the DNA longitudinally, thereby providing for the dense packing of DNA and protein seen in the polytene bands while the intervals between loops would correspond to the interbands where the packaging of DNA and protein is much less dense.

Therefore the six billion bases packaged in higher order chromatin structure are not defined beyond the loop structure, even though packaging studies and electron microscopy assert that a higher packaging ratio exists. With the loop structure, DNA will reduce its length by another factor of about 25 , yielding a total compaction of about $25 \times 40=1000$. With this packaging ratio, free DNA will conform into the typical structure of the dispersed, interphase chromosome. So when a cell divides, it will only have to reduce the size of its chromosomes by a further factor of about 10 , in order to reach the total compaction of 10,000 fold as mentioned above. Filipski et al (1990) proposed the organization of chromatin loops into the 200-300 nm thick chromatin fiber (Comings, 1977; Boy de la tour and Laemmli, 1988), a model whereby the $50 \mathrm{~kb}$ loops are arranged into hexameric rosettes containing $300 \mathrm{~kb}$ of DNA forming a fiber of $200-300 \mathrm{~nm}$ in diameter. Furthermore, rosettes were proposed to follow a helical path to form a coil. A coil contains approximately 30 rosettes. An averaged size human chromosome contains 10 such coils (fig.3), which is similar to the average number of coils observed in the electron microscope. This model agrees well with all known features of chromatin and chromosomes. The identification of matrix proteins and their role in higher order chromatin packaging is of paramount significance such as the determination of the functional genetic domains that are regulated in development and adulthood. In addition, structural organization of chromatin and chromatin fragmentation studies, especially those induced by oxidative stress, help identify hot spots responsible for chromosome rearrangements and mutations. 

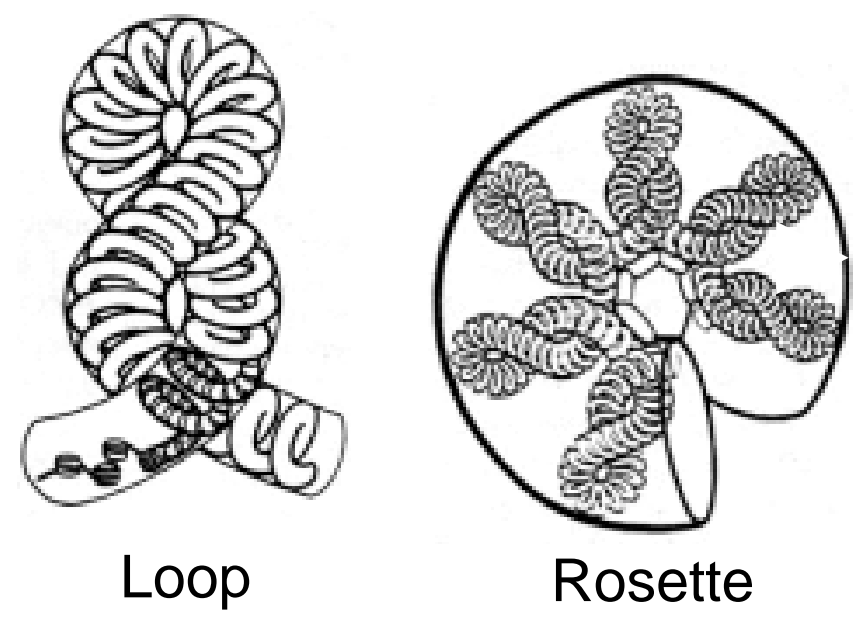
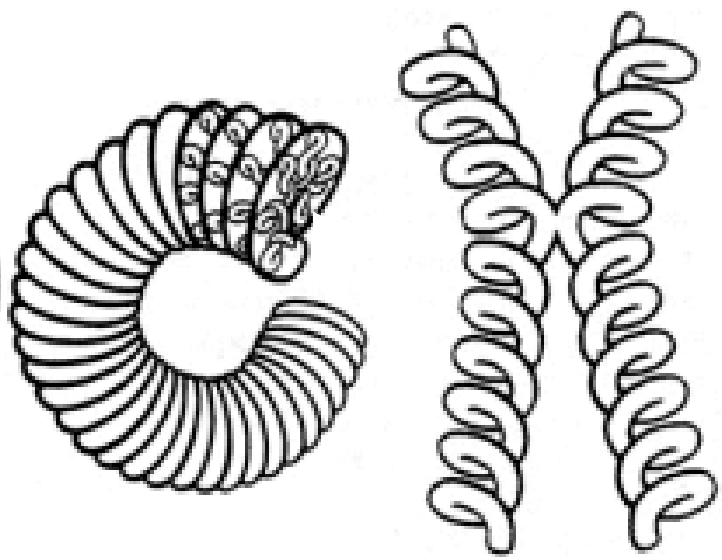

Coil

Sister chromatids

Figure 3. Proposed model of the higher order chromatin folding in chromosomes. Filipski et al., 1990.

\subsection{Chromatin Fragmentation and Programmed Cell Death (PCD)}

Cell death can be classified into two categories: programmed cell death (PCD) and accidental cell death. PCD is an active form of cell elimination that is observed during development (Williamson, 1970) and also termed apoptosis (Kerr et al., 1972). For example, during embryonic and early postnatal development, approximately 50\%, of neurons in the nervous system die after being unable to synapse with neighboring cells (Oppenheim 1991). Deletions of oligodendrocytes unable to myelinate axons (Barres et al., 1992) as well as deletion of cells from interdigital regions of the hand (Garcia-Martinez V et al., 1993) are carried out by apoptosis. Therefore, PCD is vital for development, and acts to sculpt and optimize functionality. PCD is also important in adults as it was detected in many human pathologies such as Alzheimer's disease, Parkinson's disease, and multiple sclerosis (Namura et al., 1998; Roperch et al., 1998). Interestingly, PCD can be observed as a consequence of uncontrolled proliferation, safeguarding tissues from tumor growths by eliminating cells that have escaped cell cycle controls (Reed CJ, 2000). PCD is genetically controlled and genes 
involved in the process have been identified: some are also involved in repair processes, tumor suppression, growth, such as PARP, p53 (Whitacre CM et al., 1995) and ras (Maru Y 2001), while others are mainly death inducing, such as the caspase genes (Colussi PA and Kumar S, 1999). Intriguingly, cells undergo PCD in an asynchronous fashion independent of the stage of the cell cycle suggesting an inherent physical property of the stimulus or the cells in vitro (Messam CA and Pittman RN (1998). Given the likelihood of biochemical and biophysical changes that occur in cells undergoing PCD in vivo and in vitro, many believe that the same asynchronous death mechanism exists in vivo.

Cells undergoing PCD show characteristic morphological changes. These changes are initially manifested by nuclear chromatin condensation along the wall of the nuclear envelope, cytoplasmic shrinkage, loss of specialized surface frameworks such as microvilli and cell-cell junctions, and nuclear fragmentation. The plasma membrane convolutes, and the cell breaks into 'apoptotic' bodies. Eventually, the apoptotic bodies become phagocytosed by neighboring cells or macrophages. Thus, because cells undergoing PCD do not release their contents into the extracellular space, they do not induce inflammatory reactions.

Following the advent of field inversion gel electrophoresis (FIGE) (Carle et al., 1986), DNA fragmentation could be examined at whole new levels. This technique described in materials and methods, allowed the opportunity to study the earliest stages of DNA degradation in programmed cell death. It is unequivocally important to note that as the internucleosomal fragmentation led to the identification of the unit of chromatin, HOCD might lead to the identification not only of a conserved chromatin domain but domains that are susceptible to fragmentation and rearrangement.

Nuclear chromatin undergoes higher order chromatin digestion (HOCD) into high 
molecular weight fragments. HOCD has been demonstrated in cells challenged with different death signals including glucocorticoids (Brown et al., 1993; Cohen et al., 1994; Zhivotovsky et al., 1994), etoposide (Cohen et al., 1994; Beere et al., 1995; Oberhammer et al., 1993), $\mathrm{N}$ methylformamide (Beere et al., 1995), and TNF (Lagarkova et al., 1995). HOCD is initiated and propagated by single strand breaks (Peitsch et al., 1993), and proceeds in two topological and temporarily distinct steps (Walker et al., 1997). Hence, the digestion commences at matrix attachment regions (MARs), which are sites where chromatin loops anchor to the nuclear matrix, and is mediated by a specific endonuclease (Pandey et al., 1994; Weaver et al., 1996; Sikorska and Walker, 1998; Liu et al., 1998). The endonuclease initially introduces single strand breaks that accumulate, and ultimately, result in double strand fragmentation of the DNA. The proposed model is shown in figure 4. First, AT-rich MARs that are highly susceptible to nucleolytic attack are excised (Bode et al., 1992). This produces very large fragments of $\geq 500 \mathrm{~kb}$. At these sites the DNA is either essentially single stranded, or in a conformation that renders it highly susceptible to single strand scission. Subsequently, the DNA is digested further into 50-300 kb fragments at MARs with lower AT content, which are more resistant to endonucleases than AT-rich MARs (Dickinson et al., 1992). Consequently, the fragmentation results in the liberation of chromatin loops from the nuclear matrix and leads to chromatin collapse (Oberhammer et al., 1993; Brown et al., 1993). So far, this higher order chromatin degradation (HOCD) is an early and invariable feature in cells undergoing programmed cell death (brown et al., 1993; Oberhammer et al., 1993; Sun et al., 1993; Cohen et al., 1994; Sun and Cohen, 1994; Walker and Sikorska, 1997; Sikorska and Walker, 1998). In some cells undergoing PCD the chromatin is further cleaved into $200 \mathrm{bp}$ oligonucleosomal fragments (Wyllie et al., 1980; Williams et al., 1990). 


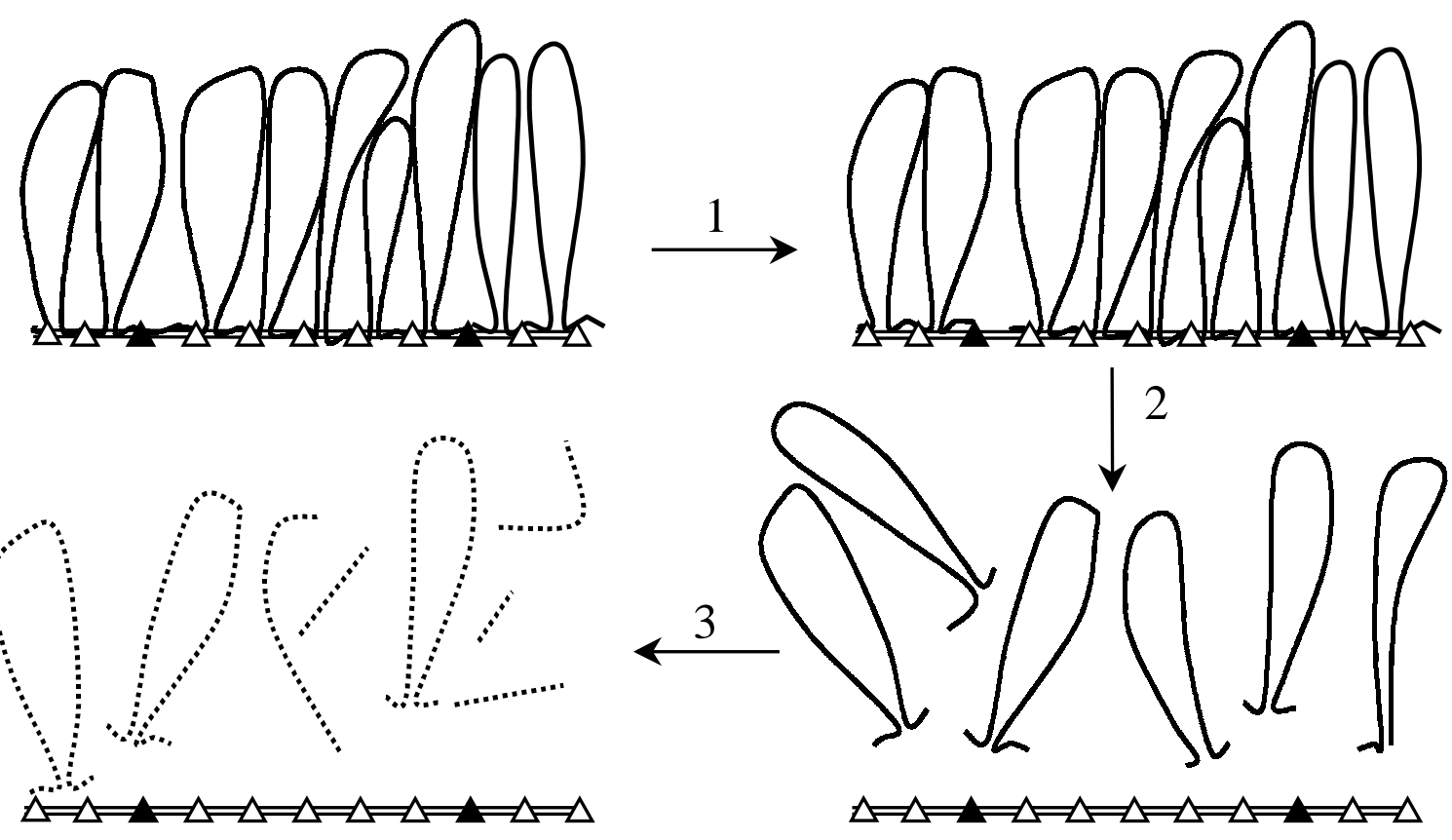

Figure 4. Proposed model for spatiotemporal digestion of chromatin during programmed cell death. Chromatin fiber is represented by the ellipses which are attached to the nuclear matrix shown as the double horizontal lines. The triangles depict MARs-associated DNase. The initial scission (1) occurs at AT-rich MARs (filled triangles), and results in the production of HMW fragments of $\geq 400 \mathrm{~kb}$. Subsequently (2), chromatin is digested at remaining MARs (open triangles) resulting in the liberation of 50-300 kb loops. This HMW cleavage is a hallmark of programmed cell death. In some cases, chromatin loops undergo internucleosomal digestion (3) producing a 200 bp ladder.

\subsubsection{Endonucleases}

In 1957, Cole and Ellis made the first observation that an endonuclease is involved in cell death. Since then, an in vivo role of endonucleases in programmed cell death has been established but, despite considerable effort, it has not been possible to identify a conserved endonuclease playing a central role in the death of all cells. Although much of the early work pointed to a $\mathrm{Ca}^{2+} / \mathrm{Mg}^{2+}$-dependent endonuclease, it is now apparent that other endonucleases catalyze or contribute to DNA fragmentation in various cell types. Indeed more than twenty different enzyme activities have been implicated. In 1974, Williams et al. associated a specific endonuclease activity with cell death in vitro using Chang liver cells and Chinese hamster 
lung cells. Similar endonuclease-mediated DNA degradation was observed in lymphocytes dying of ionizing radiation (Skalka, et al., 1976). Interestingly, programmed cell death and chromatin fragmentation studies allowed the first observation of DNA degradation into discrete oligomeric fragments that later, promoted the identification of the nucleosome. However, not all programmed cell deaths lead to internucleosomal fragmentation while higher order chromatin degradation is the hallmark of such death (Saikorska and Walker, 1998). Endonucleases involved in programmed cell death are not defined beyond their cationic requirements $\left(\mathrm{Ca}^{2+}, \mathrm{Mg}^{2+}\right)$, $\mathrm{pH}$ dependence and their inhibition by zinc. Endonucleases implicated in HOCD and internucleosomal fragmentation have a average molecular weight of 40kD (Khodarev et al., 1998). Different cells express different endonucleases in their nuclear compartments (Khodarev et al., 1998). Furthermore, a change in endonuclease activity has been observed during development and differentiation (Anzai et al., 1995, Kawabata et al., 1996, Fimia et al., 1996). Activation of endonucleases might result from change in conformation of chromatin rendering it susceptible to nucleolytic attack. Internucleosomal fragmentation seems to be distinct from HOCD based on the selective inhibition of the former by protease inhibitors like dichloroisocoumarin. (Weaver et al., 1996; Hara et al., 1996). Hence, proteolysis can be ruled out for initiation of programmed cell death. Endonucleases do not cleave specific DNA sequences however they do have preference to tracts of DNA that have the tendency to bend and was confirmed to start at MARs (Hermann et al., 1996; Lagarkova et al., 1995). In addition, collapse of chromatin structure was shown to results from HOCD and is sufficient to cause death of the cells. (Oberhammer et al., 1993). 


\subsection{Oxidative Stress (OS)}

With the enrichment of the biosphere with molecular oxygen two and a half billion years ago, organisms started to use oxygen as a source of oxidant to biodegrade organic compounds and generate a higher yield of energy. Unfortunately cells had to succumb to the fact that unnecessary oxidation reactions with other biological molecules are inevitable with the presence of a strong oxidant like oxygen that generates reactive oxygen species (ROS). As defense mechanisms to reduce the production and increased elimination of ROS evolved, cells acquired tolerance to low levels of ROS. With time, cells used these ROS as a defense weapon against pathogens. ROS have a biological role necessary for normal function of cells of the immune system in mammals. In addition, ROS can act as second messengers to stimulant-dependent signaling (Rhee S, 1999). Hence, OS is defined as a disruption of a balance between ROS production and elimination.

\subsubsection{Reactive Oxygen Species (ROS)}

ROS cause an oxidative disintegration of all biological macromolecules. With respect to the target cell, ROS originate either endogenously as in ischemia and reperfusion, or exogenously as in inflammation. The major sites of ROS production are the mitochondria and cell membranes. In mitochondria, $2-5 \%$ of oxygen is converted to superoxide anion $\left(\mathrm{O}_{2}{ }^{\circ}\right)$. This superoxide production results from electrons leaking from the respiratory chain. Thus, oxygen is reduced by one electron to produce $\mathrm{O}_{2}{ }^{-}$. However, $\mathrm{O}_{2}{ }^{-}$is produced largely extracellularly as part of the respiratory burst phenomenon common to immune cells such as 
neutrophils, macrophages and microglia. This is mediated by the membrane-bound NADPH oxidase (Sankarapandi et al., 1998) that catalyzes the following reaction:

$$
2 \mathrm{O}_{2}+\mathrm{NADPH} \longrightarrow 2 \mathrm{O}_{2}{ }^{\bullet}+\mathrm{NADP}^{+}+\mathrm{H}^{+}
$$

$\mathrm{O}_{2}{ }^{-}$is a weak oxidant that spontaneously dismutates to hydrogen peroxide $\left(\mathrm{H}_{2} \mathrm{O}_{2}\right)$.

$$
2 \mathrm{O}_{2}{ }^{-}+2 \mathrm{H}^{+} \longrightarrow \mathrm{H}_{2} \mathrm{O}_{2}+\mathrm{O}_{2}
$$

A specific enzyme, superoxide dismutase, evolved to speed up this reaction. $\mathrm{H}_{2} \mathrm{O}_{2}$ is also produced from organic substrates in peroxisomes by an oxidation reaction:

$$
\mathrm{RH}_{2}+\mathrm{O}_{2} \longrightarrow \mathrm{R}+\mathrm{H}_{2} \mathrm{O}_{2}
$$

$\mathrm{H}_{2} \mathrm{O}_{2}$ is a noxious compound because it can easily cross biological membranes (Frimer et al., 1984), and can be non-enzymatically converted into the hydroxyl radical $\left(\mathrm{OH}^{\circ}\right)$ in the presence of reduced transition elements such as $\mathrm{Fe}^{2+}$ or $\mathrm{Cu}^{2+}$ (Halliwell and Gutteridge, 1989). $\mathrm{OH}^{\bullet}$ has a diffusion radius of $0.3 \mathrm{~nm}$ before it interacts with another molecule (Beckman et al., 1994). The reaction is termed Fenton reaction:

$$
\mathrm{H}_{2} \mathrm{O}_{2}+\mathrm{Fe}^{2+} \longrightarrow \mathrm{OH}^{\bullet}+\mathrm{OH}^{-}+\mathrm{Fe}^{3+}
$$

The highly reactive $\mathrm{OH}^{\bullet}$ can damage proteins, lipids, and nucleic acids directly or indirectly through the generation of secondary radicals, and consequently causes considerable cell and tissue damage (Slater, 1984). $\mathrm{H}_{2} \mathrm{O}_{2}$ and iron can generate $\mathrm{OH}^{\bullet}$ through a Haber-Weiss reaction, where $\mathrm{O}_{2}{ }^{-}$reacts with $\mathrm{H}_{2} \mathrm{O}_{2}$, while iron acts as a catalyst in (Haber and Weiss, 1934)

$$
\mathrm{O}_{2}{ }^{\bullet-}+\mathrm{H}_{2} \mathrm{O}_{2} \longrightarrow \mathrm{OH}^{\bullet}+\mathrm{OH}^{-}+\mathrm{O}_{2}
$$

A typical human cell generates $3 \times 10^{9}$ molecules of $\mathrm{H}_{2} \mathrm{O}_{2}$ per hour (Martin et al., 1996). Interestingly, at concentrations below $5 \mu \mathrm{M}, \mathrm{H}_{2} \mathrm{O}_{2}$ was found to exert a mitogenic effect on cells (Kelvin and Davies, 1999). In effect, $\mathrm{H}_{2} \mathrm{O}_{2}$ has been found to have a role as a second 
messenger in several cell types (May and De Haen, 1979; Ohba et al., 1994; Sundaresan et al., 1995; Rae et al., 1997).

In the presence of myeloperoxidase, a heme containing enzyme found in cytoplasmic granules (Oren and Taylor, 1995), neutrophils convert $\mathrm{H}_{2} \mathrm{O}_{2}$, using the ubiquitous chloride ion, into the potent oxidant, hypochlorite $\left(\mathrm{ClO}^{-}\right)$(Weiss, 1989):

$$
\mathrm{Cl}^{-}+\mathrm{H}_{2} \mathrm{O}_{2} \longrightarrow \mathrm{ClO}^{-}+\mathrm{H}_{2} \mathrm{O}
$$

Hypochlorite, in turn, reacting with $\mathrm{H}_{2} \mathrm{O}_{2}$, can give rise to singlet oxygen $\left({ }^{1} \mathrm{O}_{2}\right)$, a very powerful oxidizing agent (Gorman et al., 1992). Another strong oxidant, peroxynitrite $\left(\mathrm{ONOO}^{-}\right)$, is produced by the reaction of nitric oxide $\left(\mathrm{NO}^{\circ}\right)$ with superoxide:

$$
\mathrm{NO}^{\bullet}+\mathrm{O}_{2}{ }^{-} \longrightarrow \mathrm{ONOO}^{-}
$$

\subsubsection{Cellular Defense Mechanisms Against ROS}

With the potential of self-destruction by ROS overproduction, cells have evolved defense mechanisms, which helped to keep a necessary homeostatic level of those species. Since the sources of ROS are numerous, the exact mechanism of regulation of these species is not well understood, and different cell types have different basal level of oxidants in their cytoplasm. The concentration at which ROS induce OS, and the ability to resist that stress, differ among various types of cells (Juurlink B, 1997). Two interplaying systems to scavenge ROS exist in cells: enzymatic and non-enzymatic defense mechanisms. 


\subsubsection{Enzymatic Defense Mechanisms}

It is interesting that nature chose to eliminate $\mathrm{O}_{2}{ }^{\bullet}$ by transforming it to the less reactive but potentially more harmful $\mathrm{H}_{2} \mathrm{O}_{2}$. This reaction is catalyzed by superoxide dismutases found in cytoplasm $\left(\mathrm{Cu} / \mathrm{Zn}\right.$ SOD) and mitochondria (MnSOD). To detoxify $\mathrm{H}_{2} \mathrm{O}_{2}$, two different enzymes evolved. Catalase, with $\mathrm{Fe}^{3+}$-based protoporphyrin centers, converts $\mathrm{H}_{2} \mathrm{O}_{2}$ into $\mathrm{H}_{2} \mathrm{O}$ and $\mathrm{O}_{2}$ in the reaction:

$$
2 \mathrm{H}_{2} \mathrm{O}_{2} \longrightarrow 2 \mathrm{H}_{2} \mathrm{O}+\mathrm{O}_{2}
$$

and glutathione peroxidase which catalyzes the conversion of $\mathrm{H}_{2} \mathrm{O}_{2}$ to water in the following reaction:

$$
\mathrm{H}_{2} \mathrm{O}_{2}+2 \mathrm{GSH} \longrightarrow 2 \mathrm{H}_{2} \mathrm{O}+\mathrm{GSSG}
$$

Glutathione peroxidase of which four isoforms are found in humans, is a selenoprotein bound to the tripeptide glutathione. Glutathione peroxidase is main enzyme involved in decomposition of $\mathrm{H}_{2} \mathrm{O}_{2}$ in the central nervous system (CNS) (Jain et al., 1991). The enzyme is found predominantly in the cytoplasm and effectively metabolizes $\mathrm{H}_{2} \mathrm{O}_{2}$ at low concentrations, but requires high concentrations of reduced glutathione (GSH) and selenium for optimal activity. GSH is regenerated by the enzyme glutathione reductase by reducing oxidized glutathione (GSSG).

\subsubsection{Non-Enzymatic Defense Mechanisms}

Vitamin $\mathrm{E}$ is an efficient lipid-soluble antioxidant that functions as a chain breaker in lipid peroxidation of cell membranes and various lipid particles. Vitamin $\mathrm{C}$ (ascorbic acid) is a water-soluble free-radical-scavenger. In vitro, ascorbate efficiently neutralizes phagocytederived extracellular oxidants while intracellular antimicrobial oxidants remain unchanged 
(Anderson and Lukey, 1987). Lipid soluble $\beta$-carotene, and carotenoids in general, are effective antioxidants which neutralize singlet oxygen and peroxyl radicals. Clinical trial results support no preventive role for beta-carotene but the epidemiologic evidence does generally support the idea that a diet rich in high carotenoid foods is associated with a reduced risk of heart and Alzheimer's diseases (Kritchevsky SB, 1999; Jimenez-Jimenez FJ et al., 1999). This suggests that oxidants are initiators of degenerative diseases however effectors are permanent oxidant-independent factors like genomic mutations.

$\mathrm{N}$-Acetyl cystein has an antioxidant property whereby it stimulates the production of reduced glutathione (GSH) which is used by glutathione peroxidase to scavenge $\mathrm{H}_{2} \mathrm{O}_{2}$ and hence alleviate OS on the cell (Yim et al., 1994). Uric acid, present at high levels in human serum, is a natural scavenger of $\mathrm{ONOO}^{-}$(Spitsin et al., 2000). Green tea polyphenol (-)epigallocatechin-3-gallate treatment to mouse skin prevents UVB-induced infiltration of leukocytes, depletion of antigen-presenting cells, and OS (Katiyar and Mukhtar, 2001). In a pilot experiment, pretreatment of oligodendrocytes with green tea extract has shown a significant reduction in $\mathrm{H}_{2} \mathrm{O}_{2}$-induced higher order chromatin damage (Unpublished data).

Several trace elements found in the human body are essential in ensuring an effective antioxidant defense system. For example, zinc is a cofactor for about 200 enzymes including the cytoplasmic antioxidant enzyme $\mathrm{Cu} / \mathrm{Zn}$ SOD. In addition, zinc competes directly with copper and iron, thereby reducing the risk of hydroxyl radical formation via Fenton/HaberWeiss reactions, vide supra. Selenite (SeL) and selenomethionine (SeM) are the most common selenium (Se) compounds taken as dietary antioxidants to reduce oxidative stress. That role is predominantly mediated by glutathione peroxidase as mentioned earlier. 


\subsection{OS and Disease}

OS has been implicated as a direct or intermediary insult in many pathologies including ischemia/reperfusion, Alzheimer disease (AD), multiple sclerosis (MS), neurodegeneration, cell death, cancer, and aging, to name a few. However, the cause of OS is still unknown. In ischemia/reperfusion OS plays a critical role in the posttraumatic damage to the central nervous system (CNS) (Love S, 1999). Ischemia/reperfusion results in mitochondrial electron leakage leading to increased generation of $\mathrm{O}_{2}{ }^{--}($Ohkohchi $\mathrm{N}$ et al., 1999). Cells within MS lesions appear to sustain OS, instigated by infiltrating inflammatory cells, and/or resident microglia (Benveniste EN, 1997; Syburra and passi, 1999). With respect to aging, the "Free radical theory of aging" (Harman D, 1994), describes the increase in oxidative damage to macromolecules as a proximal mechanism of aging in aerobic organisms. OS has been shown to elicit a range of reactions depending on the level of stress incurred on the cell. For example, in proliferating as well as non-proliferating cells, oxidative stress, and especially that induced by $\mathrm{H}_{2} \mathrm{O}_{2}$, is manifested by a mitogenic, growth arrest or death response as a result of mild $(3-15 \mu \mathrm{M})$, moderate $(150-400 \mu \mathrm{M})$ or severe $(0.5-10 \mathrm{mM})$ level of stress, respectively (reviewed by K. Davies, 1999).The determination of the mechanisms of such reactions to $\mathrm{H}_{2} \mathrm{O}_{2}$ is of paramount significance to understanding the basis of life and death of cells.

Reports of deaths incurred by OS show several types of damage, such as lipid peroxidation (Deby and Goutier, 1990), loss of intracellular calcium homeostasis (PersoonRothert et al., 1994), alteration of metabolic pathways (Ben-Yoseph et al., 1994), depletion of nucleotide coenzymes (Tretter and Adam-Vizi, 2000), destruction of repair and defense 
systems (Davies KJ, 2000) and most importantly nucleic acid fragmentation (Duvall and Willie, 1986). Since higher order chromatin fragmentation is the hallmark of PCD (Sikorska and Walker, 1998), and OS being a major element contributing to neurodegeneration, autoimmune diseases and aging, the elucidation of the mechanism of such damage and assessment of its reversibility will open an unprecedented therapeutic window of opportunity for intervention. Furthermore, since mutations can be incurred in oxidatively stressed cells, identifying the mechanism of such damage will provide a better monitoring of carcinogenesis.

\subsubsection{Calcium in OS}

Given the ubiquitous nature of calcium and its role as a second messenger in many constitutive biological processes, like growth and differentiation, it is not surprising to find that even in a time of stress, the cell inevitably employs calcium as a key factor to signal for a stress response. In resting cells, $99.99 \%$ of calcium is mostly bound to proteins or stored in mitochondria or the endoplasmic reticulum, while very little calcium, approximately $100 \mathrm{nM}$, is left free in the cytosol. Extracellular calcium is found at concentrations between 1-2 mM. Cells have adapted to this chemical gradient (10,000 fold) in order to rapidly detect changes in the microenvironment. The gradient is set by special $\mathrm{Ca}^{2+}$ pumps present in the plasma, inner-mitochondrial and the endoplasmic-reticulum membranes. $\mathrm{Ca}^{2+}$ pumps in the plasma membrane use ATP hydrolysis to transport calcium out of the cell, while the pump in the mitochondrion and endoplasmic reticulum, because it is flipped inside out, transports calcium into the organelle matrix. As a second messenger, calcium activates (Scheid et al., 1999; Sanches et al., 1998; Ibitayo et al., 1998) or inhibits (Lian et al., 1998; Zhou et al., 1998) protein kinases, which have effects ranging from growth to degradation of chromatin to death 
of the cell. Change in redox potentials of pulmonary artery cells generated by oxidizing agents such as superoxide promote potassium channel closure with subsequent membrane depolarization and $\mathrm{Ca}^{2+}$ entry via activation of voltage-sensitive calcium channels (Yuan et al., 1994).

Also, in the context of OS, the role of calcium was correlated with death of the cell (Laiho and Trump, 1974). Calcium is an early mediator of cell injury and, since the introduction of the concept of active form of cell death or "programmed cell death" by Lockshin in 1969, scientists have searched for the mechanism behind this death process. Chromatin fragmentation into 200bp fragments, suggesting internucleosomal fragmentation, was an early determinant marker for programmed cell death and a $\mathrm{Ca} / \mathrm{Mg}$-dependent endonuclease similar in function to micrococcal nuclease was found to be involved in vitro and in vivo during the death process (Williamson 1970; Williams et al., 1974; Skalka et al., 1976; Zakarian and Pogossian, 1978; Bachvaroff, et al., 1977). It is useful to note here that dying cells were found during development and after treatment with several agents like the calcium ionophore, tritiated thymidine, glucocorticoids, and ionizing irradiation, suggesting that common pathways are involved.

It was not until the late eighties however, when Jones and his colleagues showed that isolated thymocyte nuclei fragment their chromatin when treated with calcium, and that happens only when an ATP-regenerating system was present, suggesting that neither calcium nor ADP or ATP alone cause direct activation of the $\mathrm{Ca} / \mathrm{Mg}$-dependent endonuclease (Jones et al., 1989). Most importantly, a study done by Yoshida and his colleagues showed that a basal level of calcium is sufficient to trigger an internucleosomal fragmentation in etoposide treated HL-60 cells (Yoshida et al., 1993). A possible mechanism of $\mathrm{H}_{2} \mathrm{O}_{2}$-induced HOCD 
entails direct activation of MAR-associated endonuclease by calcium ions. This notion is supported by the observation that $\mathrm{H}_{2} \mathrm{O}_{2}$ rapidly increases intracellular free calcium concentrations in various cells (Hyslop et al, 1986; Josephson et al, 1991; Ueda \& Shah, 1992), and that the putative MAR-associated endonuclease, i.e., DNase $\mathrm{Y}$ is calcium/magnesium-dependent (Liu et al. 1998). Also, calcium has been shown to be required for HOCD in methylprednisolone-treated thymocytes (Zhivotovsky et al, 1994). However, it is also possible that calcium activates MAR-associated endonuclease indirectly by mediating upstream signaling events induced by $\mathrm{H}_{2} \mathrm{O}_{2}$, or that the activation is calcium-independent.

\subsubsection{Magnesium in OS}

As calcium-mediated reactions are much faster than those of magnesium, and free calcium gradient across cells $(100 \mathrm{nM} / 1 \mathrm{mM})$ is much higher than that of magnesium $(5000 \mathrm{nM} / 1 \mathrm{mM})$, it has been proposed that calcium acts as an acute on-off second messenger, whereas magnesium acts as a chronic regulator of a biological process (Grubbs and Maguire 1987). In cells, magnesium is associated with phosphates, and calcium is tightly bound to proteins. Magnesium has ubiquitous and essential biochemical roles, such as function maintainance, structure stabilization, energy transduction and metabolism regulation. At the biochemical level, calcium and magnesium are known to act antagonistically towards each other. For example, many enzymes whose activities critically depend on a sufficiency of intracellular magnesium, especially transphosphorylases, will be detrimentally affected by small increments in levels of cellular calcium ions. Growth of cells, cell-cycle progress and intermediary metabolism are also absolutely dependent on the bioavailability of magnesium, which can be compromised if excess calcium is present. In addition, there is evidence that 
heat-stressed cells lose magnesium, but gain calcium. For example, heat-shocking yeast cells opens up mechano-sensitive calcium channels and causes leakage of magnesium (Piper, P. 1997; Walker, G. M., 1998). Magnesium has been implicated in the induction of $\mathrm{Ca} / \mathrm{Mg}$ endonucleases associated with chromatin fragmentation, vide supra. Furthermore, $\mathrm{Mg}$ dependent $\mathrm{Ca}$-independent endonucleases have been isolated and these endonucleases were implicated in the higher order chromatin fragmentation that has been observed in all dying cells (Kawabata et al., 1993).

\subsection{Oligodendrocytes}

Oligodendrocytes (OLs) are the myelin sheath-producing and -maintaining glial cells of the central nervous system (CNS). Myelin, constituting $60 \%$ of white matter dry weight, is required for the efficient propagation of axonal impulses, and is highly susceptible to ROS attack that leads to lipid and protein peroxidation (Chia et al., 1983; Konat \& Wiggins 1985; Konat et al., 1986). OL constitute $70 \%$ of white matter cells (Foster \& Brown, 1997). OL may play a very important role in regulating ionic (Crammer et al., 1985; Kettenmann et al., 1983) and neurotransmitter (Reynolds \& Herschkowitz, 1986) homeostasis of the tissue that is critically distorted under OS. In addition, OLs contain most of the brain carbonic anhydrase, which would make them regulators of $\mathrm{pH}$ in the tissue (Crammer et al., 1985). Recent in vivo studies show that OL are highly vulnerable to ischemia/reperfusion, for example, their degeneration and death precedes by several hours the death of cortical neurons under experimental focal ischemia (Pantoni et al., 1996; Petito et al., 1998). Furthemore, cultured OL are readily injured by hypoxia/reoxygenation, whereas astrocytes, their glial counterpart, which contribute to the blood brain barrier, survive (Juurlink \& Hertz, 1993; Husain \& 
Juurlink, 1995). Furthermore, OL generate six times more ROS than astrocytes under normal conditions, as well as under stress (Thorburne \& Juurlink, 1996), and are also preferentially damaged by exogenous ROS (Kim \& Kim, 1991; Noble et al., 1994; Husain \& Juurlink, 1995).

Because of their high concentration of unsaturated fatty acids (Svennerholm et al 1978) that may yield secondary free radicals, as well as thromboxanes and leukotrienes (Demediuk \& Faden, 1988; Xu et al., 1990), peroxidizing myelin sheaths are likely to sustain or even aggravate the oxidative stress of oligodendrocytes within lesions. In addition to their high unsaturated fatty acid content, OL's susceptibility to OS is due to their large iron store and low level of glutathione as these enhance ROS accumulation (vide supra).

OS of myelin-maintaining oligodendrocytes is emerging as a pivotal factor in acute neurodegeneration. Thus, the extensive white matter degeneration following an ischemic insult to the CNS (Oppenheimer et al, 1995; Blisard et al, 1995; Mehta et al, 1996) may be related to the high vulnerability of oligodendrocytes. Ischemia, and the consequent oxidative stress also play a critical role in the post-traumatic damage (Bartholdi \& Schwab, 1995; Tator \& Koyanagi, 1997; Zhang \& Guth, 1997). Moreover, oxidative damage of oligodendrocytes may underlie inflammatory demyelination within multiple sclerosis lesions (Mitrovic et al, 1995; Hooper et al. 1997, 1998). Prolonged treatment of cultured oligodendrocytes with $\mathrm{H}_{2} \mathrm{O}_{2}$ has been shown to be cytotoxic (Kim \& Kim, 1991; Noble et al, 1994). In a previous study we showed that even 15-min exposure of oligodendrocytes to $\mathrm{H}_{2} \mathrm{O}_{2}$ instigates a delayed degeneration characteristic of programmed cell death (Laszkiewicz et al., 1999). The concomitant higher order chromatin fragmentation (fig. 5) led to further analysis of the vulnerability of chromatin to $\mathrm{H}_{2} \mathrm{O}_{2}$. Hence, higher order chromatin fragmentation, being an 
early hallmark of programmed cell death, was assessed in subsequent studies to unravel the mechanism through which $\mathrm{H}_{2} \mathrm{O}_{2}$ induced this fragmentation.

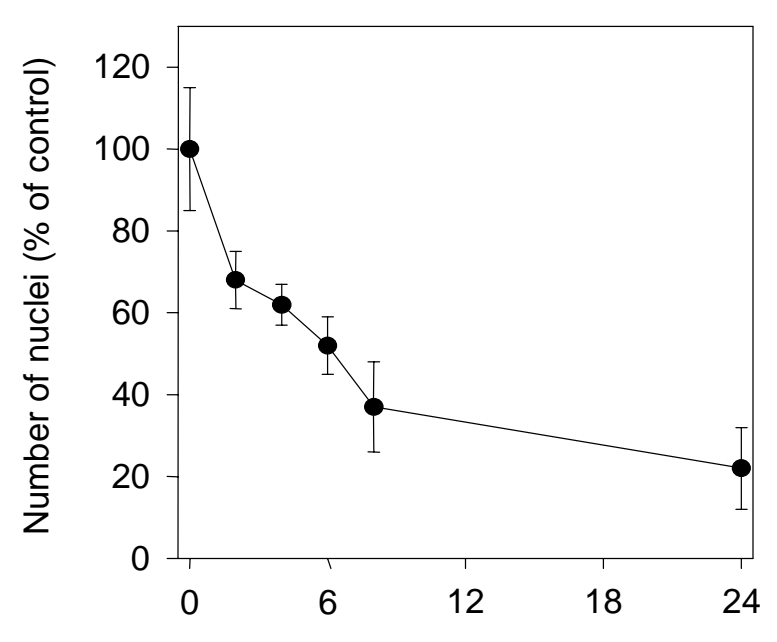

Hours of recovery

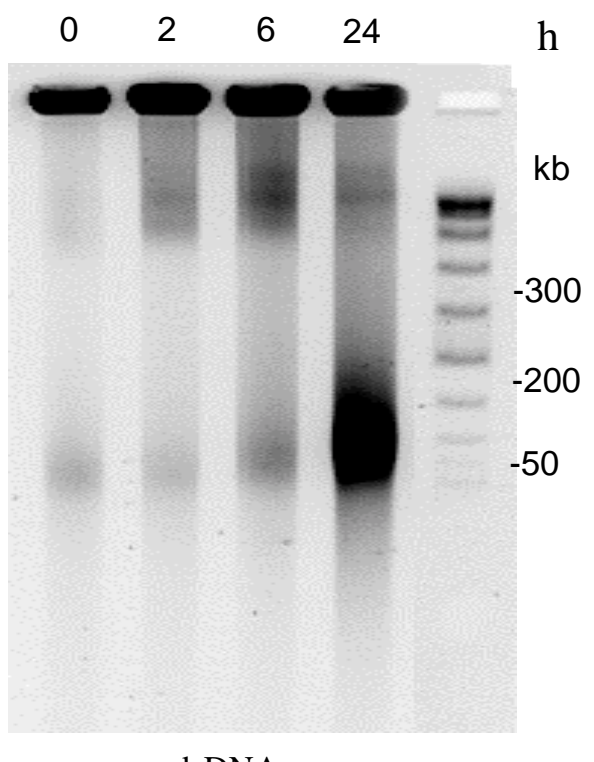

dsDNA

Figure 5. Delayed oligodendrocyte death following a brief exposure to $4 \mathrm{mM} \mathrm{H}_{2} \mathrm{O}_{2}$.. Left panel: cells were treated with $\mathrm{H}_{2} \mathrm{O}_{2}$ for $15 \mathrm{~min}$, and analyzed at different time points for up to $24 \mathrm{hr}$. cell survival was estimated by nuclear counting. Right panel: Higher molecular weight DNA fragmentation in oligodendrocytes. Experimental conditions were like above. Cells were harvested, embedded in agarose and the DNA was purified by SDS extraction. The picture shows a negative of ethidium bromide-stained gel. Lane 1 shows control (untreated) cells. Lanes 2, 3 and 4 represent cells 2, 6, and $24 \mathrm{hr}$ after $\mathrm{H}_{2} \mathrm{O}_{2}$ treatment, respectively. Lane 5, concatenated lambda chromosome (lambda ladder).

\section{6. $\quad$ C6 cells as a model of oligodendrocytes}

C6 cells are chemically induced CNS-derived rat glioma cells (Benda et al., 1968). C6 cells have both astrocytic and oligodendrocytic properties, expressing low levels of glial fibrillary acidic protein and myelin genes, respectively (Pfeiffer et al., 1970; Bissell et al., 1974; Volpe et al., 1975). C6 do not produce myelin structures. Primary oligodendrocytic cultures are very useful in biochemical and genetic studies of myelinogenesis however, due to 
their paucity and because $\mathrm{C} 6$ cells show similar kinetics of H2O2-induced HOCD compared to OL, C6 cells were used as a model of OL.

This study was undertaken to test the following hypotheses:

1. $\mathrm{H}_{2} \mathrm{O}_{2}$ induces a rapid HOCD in OL

2. The DNA fragmentation is irreversible.

3. HOCD does not result from calcium influx into the cells, but rather from a specific signal cascades triggered by $\mathrm{H}_{2} \mathrm{O}_{2}$. 


\section{MATERIALS AND METHODS}

\subsection{CHEMICALS}

Ethylenediaminetetraacetic acid (EDTA) (Sigma \# E5134), ethylene glycol-bis( $\beta$ aminoethyl ether)-N,N,N',N'-tetraacetic acid (EGTA) (Sigma \# E8145), calcium chloride (Sigma \# C7902), magnesium sulfate $\left(\mathrm{MgSO}_{4}\right)$ (Sigma \# M2643), ethanol (Sigma \# E7148), trypan blue (Allied chemical corporation, New York, NY; \# 508), TRIZMA Base (Sigma \# T8524), borate (Sigma \# B6768), NaCl (Sigma \# S3014), ZnCl 2 (Sigma \# Z3500), spermine (Sigma \# S2876), spermidine (Sigma \# S2501), KCl (Sigma \# P5405), sucrose (Sigma \# S5016), phenylmethylsulfonylfluoride (PMSF) (Sigma \# P7626), DTT (Sigma \# D9779), ethidium bromide (Sigma \# E8751), metrizamide (Sigma \# M3383), uric acid (Sigma \# U2625), pulse field certified agarose (BIO-RAD, Hercules, CA; \# 162-0137), low melting point agarose (UltraPURE, Gaithersburg, MD) sodium bicarbonate $\left(\mathrm{NaHCO}_{3}\right)$ (Sigma \# S5761), sodium dodecylsulfate (SDS) (Sigma \# L4390).

\subsection{REAGENTS}

$3 \%$ hydrogen peroxide was purchased from the local pharmacy. BAPTA/AM, Deferoxamine methylate (DFO), TMB-8, and A23187 were purchased from Calbiochem, La Jolla, California. Concatenated lambda phage DNA ladder was purchased from BioRad, Hercules, CA. $\beta$-mercaptoethanol, acetic acid, dimethylsulfoxide (DMSO), proteinase K, RNase A and glycerol were purchased from Sigma Aldrich, St Louis, MO. Nonidet-P40 was 
purchased from Bioworld, Dublin, OH. S1 nuclease was purchased from Boehringer Mannheim, Indianapolis, IN.

\subsection{CALCIUM AND IRON REAGENTS}

BAPTA/AM [1,2-bis $(o-$ Aminophenoxy)ethane-N,N,N',N'-tetraacetic acid tetra(acetoxymethyl) ester] The membrane-permeable form of BAPTA, BAPTA/AM is hydrolyzed by cytosolic esterases and is trapped intracellularly as the active chelator BAPTA. BAPTA is a $\mathrm{Ca}^{2+}$ chelator exhibiting a $10^{5}$-fold greater affinity for $\mathrm{Ca}^{2+}$ than for $\mathrm{Mg}^{2+}$. Stock $1 \mathrm{X}=50 \mu \mathrm{M}$ in Hank's.

A23187 (calcimycin) is a mobile ion-carrier ionophore that forms stable complexes with divalent cations, allowing them to freely pass through the plasma membrane. It is used to increase intracellular calcium levels thousand fold. Stock $1 \mathrm{X}=5 \mu \mathrm{M}$ in DMSO.

TMB-8 [8-(N,N-Diethylamino)-ocyl-3,4,5-trimethoxybenzoate, hydrochloride] Intracellular antagonist of $\mathrm{Ca} 2+$ release from stores. Stock $1 \mathrm{X}=10 \mu \mathrm{M}$ Solubilized in HBSS.

Deferoxamine mesylate (DFOM) Cell membrane permeable iron chelator. Stock $1 X=5$ $\mathrm{mM}$ in HBSS.

\subsection{ANIMALS}

3 month old pubescent Long-Evans hooded rats were purchased from (Charles River Laboratories, Wilmington, MA). Mating was initiated by placing a male with a female in the same cage for a week. After removal of the male, the female is registered as pregnant and predicted to give birth in at least 21 days, the average gestation period of a female rat. Within 
two days after complete delivery, rat pups are separated from their mother and used for experimental purposes. The female is left to rest in the cage for one or two days before next mating. Because breeding females produce much less progeny at an age over six months, breeders used were replaced every six months.

\subsection{OLIGODENDROCYTE CULTURE}

Oligodendrocyte precursors $(\mathrm{O}-2 \mathrm{~A})$ were prepared from primary mixed glial cultures established from newborn rat brains by the sequential dislodging procedure of McCarthy and De Vellis (1980), essentially as described by Grubinska et al. (1994). Newborn (younger than 48 hours) rat brains were aseptically dissected out and placed in a $100 \mathrm{~mm}$ Petri dish with 5 $\mathrm{ml}$ of medium A on ice water. The meninges were removed by rolling the brains over on autoclaved paper tissue and picking them off along with the blood vessels, using a pair forceps. The brains were placed in another $100 \mathrm{~mm}$ Petri dish with medium A (approximately $5 \mathrm{ml} / 10$ brains) on ice water, then the tissue was minced into small pieces with a razor blade. The tissue slurry was transferred into a $100 \mathrm{ml}$ bottle, the dish was washed with $5 \mathrm{ml}$ medium A, combined with the slurry before adding medium B to a final DNase concentration of $10 \mu \mathrm{g} / \mathrm{ml}$. The tissue was incubated at $37^{\circ} \mathrm{C}$ for 30 min while shaking on a rotary shaker using 102-119 strokes per min. The trypsinization was stopped by adding equal volume of medium $\mathrm{C}$ then the tissue was triturated 5 to 7 times through a $10 \mathrm{ml}$ pipette and the chunks were sedimented on ice water for a few minutes. The supernatant was decanted and passed through a $74 \mu \mathrm{m}$ nylon mesh under a light vacuum. Medium $\mathrm{C}$ was added to the remaining tissue chunks to triturate and process as above until all tissue was 
dispersed. The cell suspension was combined and centrifuged at $1250 \mathrm{rpm}$ for $5 \mathrm{~min}$ at $4^{\circ} \mathrm{C}$ using JS13.1 rotor (Beckman). The pellet was collected and resuspended in medium E (approximately $2 \mathrm{ml}$ per 3-4 brains) before the cells from 3-4 brains were plated into $75 \mathrm{~cm}^{2}$ flask (approximately 50x10 $0^{6}$ cells) (Falcon, Lincoln Park, NJ \# 35-3824). The mixed glial cultures were replenished with $12 \mathrm{ml}$ medium E after $24 \mathrm{~h}$ and then every other day for a week.

Oligodendrocytes cultures were prepared by preshaking 7 day old primary glial cultures on an orbital shaker (Forma Scientific, Marietta, OH) at $200 \mathrm{rpm}$ at $37^{\circ} \mathrm{C}$ for $1 \mathrm{~h}$. Fresh $12 \mathrm{ml}$ medium was added to the flasks and these were placed for $2-3 \mathrm{~h}$ in a $95 \%$ air$5 \% \mathrm{CO}_{2}$ incubator. Primary mixed glia in the flasks were shaken overnight (16-20 hours) as above, before the medium containing detached cells was decanted and passed through a 74 $\mu \mathrm{m}$ nylon mesh. The flasks were replenished with medium $\mathrm{E}$ and subjected twice through the same cycle of incubation, preshake and shake before discarding them. The first shake yielded the largest number of O-2A cells. The detached O-2A cells were preplated by dividing the volume collected into an equal number of shaken flasks and incubating them at $37^{\circ} \mathrm{C}$ in incubator. After $2 \mathrm{~h}$ of preplating, flasks were swirled 25 times by hand in each direction to detach loosely attached O-2A cells. The medium was collected and centrifuged at $1250 \mathrm{rpm}$ for $5 \mathrm{~min}$ at $4^{\circ} \mathrm{C}$. O-2A cells were resuspended in an appropriate volume of medium E. A sample was taken from the suspension for counting the cells in a hemocytometer. O-2A cells were seeded in $10 \mathrm{~cm}^{2}$ Primaria dishes (Falcon \# 35-3801) at a density of $1.5 \times 10^{6}$ cells per $3 \mathrm{ml}$ of medium $\mathrm{E}$ and grown overnight for the cells to attach to the stratum of the dish. After the cells attached, and every other day, the medium was changed to OEM to differentiate the 
precursor O-2A cells. After 6 days in culture, more than $95 \%$ of the cells were mature OL, as demonstrated by immunostaining for the specific surface antigen, galactocerebrosides (Gu et al., 1997) by the full upregulation of myelin-specific genes (Grubinska et al., 1994) and the whorls, consisting of myelin membranes, that were ubiquitously observed under the inverted light microscope.

\subsection{C6 CELL CULTURE}

C6 cells (CCL 107, passage 45) were purchased from American Type Culture Collection (Rockville, MD). Stock monolayer cultures were maintained in medium E at $37^{\circ} \mathrm{C}$ under $95 \%$ air $5 \% \mathrm{CO}_{2}$. After detachment from the surface and separation of stock culture cells with trypsin-EDTA, $1.5 \times 10^{6}$ cells in medium E were plated in $10 \mathrm{~cm}^{2}$ Primaria dishes (Falcon, Lincoln Park, NJ, \#35-3801) for approximately two h until they adhere to the surface of the dish. Once the cells attached, the medium was changed to medium D (no serum) to reduce the cells' proliferation rate during overnight incubation prior to the treatment. Following treatment, the cells were collected or allowed to recover in medium D. At desired time points, the reaction was stopped by replacing the medium with ice-cold embedding buffer. The cells were scraped with a sterile scraper (Costar, Cambridge, MA; \# 3010), pelleted by centrifugation at $1250 \mathrm{rpm}, 4^{\circ} \mathrm{C}$ for $5 \mathrm{~min}$ and embedded in $0.8 \%$ low melting point agarose. 


\section{7. $\underline{\mathrm{H}}_{2} \underline{\mathrm{O}}_{2} \underline{\text { EXPOSURE }}$}

The cells were washed in HBSS containing no phenol red to avoid interference with hydrogen peroxide however, this HBSS contains $0.14 \mathrm{~g} / \mathrm{L}$ anhydrous calcium chloride and $0.098 \mathrm{~g} / \mathrm{L}$ anhydrous magnesium sulfate (GibcoBRL \# 11201-092). Two milliliters of the desired $\mathrm{H}_{2} \mathrm{O}_{2}$ concentration in HBSS was then added on the cells and incubated for the desired amount of time. The concentration of $\mathrm{H}_{2} \mathrm{O}_{2}$ in the stock solution was determined spectrophotometrically approximately every three months at $\lambda=240 \mathrm{~nm}$ using the extinction coefficient $\varepsilon=43.7 \mathrm{M}^{-1} \mathrm{~cm}^{-1}$ and the formula $\mathrm{A}=\varepsilon \mathrm{cl}$ where $\mathrm{A}$ is the absorbance, $\mathrm{c}$ is the concentration and 1, the width of the cuvette. Following the treatment, the cells were either directly embedded in agarose, or embedded after allowing them to recover in OEM for desired time points. Cell viability was measured by trypan blue exclusion and counting in a hemocytometer under the light microscope.

\subsection{AGAROSE EMBEDDING \& DNA PURIFICATION}

Medium was immediately removed from control and treated cells and dishes were placed on ice-cold water. Ice cold embedding buffer was added to stop the reaction and scrape the cells with a rubber policeman. All attached cells were collected as no cells were left in the dish, as observed under the light microscope. The cells were suspended in $200 \mu \mathrm{l}$ of embedding buffer containing $0.8 \%$ low melting point agarose (fig.2), and a rod with a diameter of $2.3 \mathrm{~mm}$ was formed using Tygon tubing attached to a $1 \mathrm{ml}$ syringe. Sometimes floating cells were collected by spinning them down at $1250 \mathrm{rpm}, 4^{\circ} \mathrm{C}$ for $5 \mathrm{~min}$, resuspended in embedding buffer and embedded separately. The embedded intact genomic 
DNA was purified by extraction of the agarose rod with extraction buffer overnight at room temperature with gentle agitation. The extraction was repeated before the rod was washed three times, $4 \mathrm{~h}$ each in TE buffer and cut into $6 \mathrm{~mm}$ long plugs with a blade. The residual protein was removed by digestion of the plugs with $40 \mu \mathrm{g}$ proteinase $\mathrm{K} / \mathrm{ml} \mathrm{TE}$ overnight at

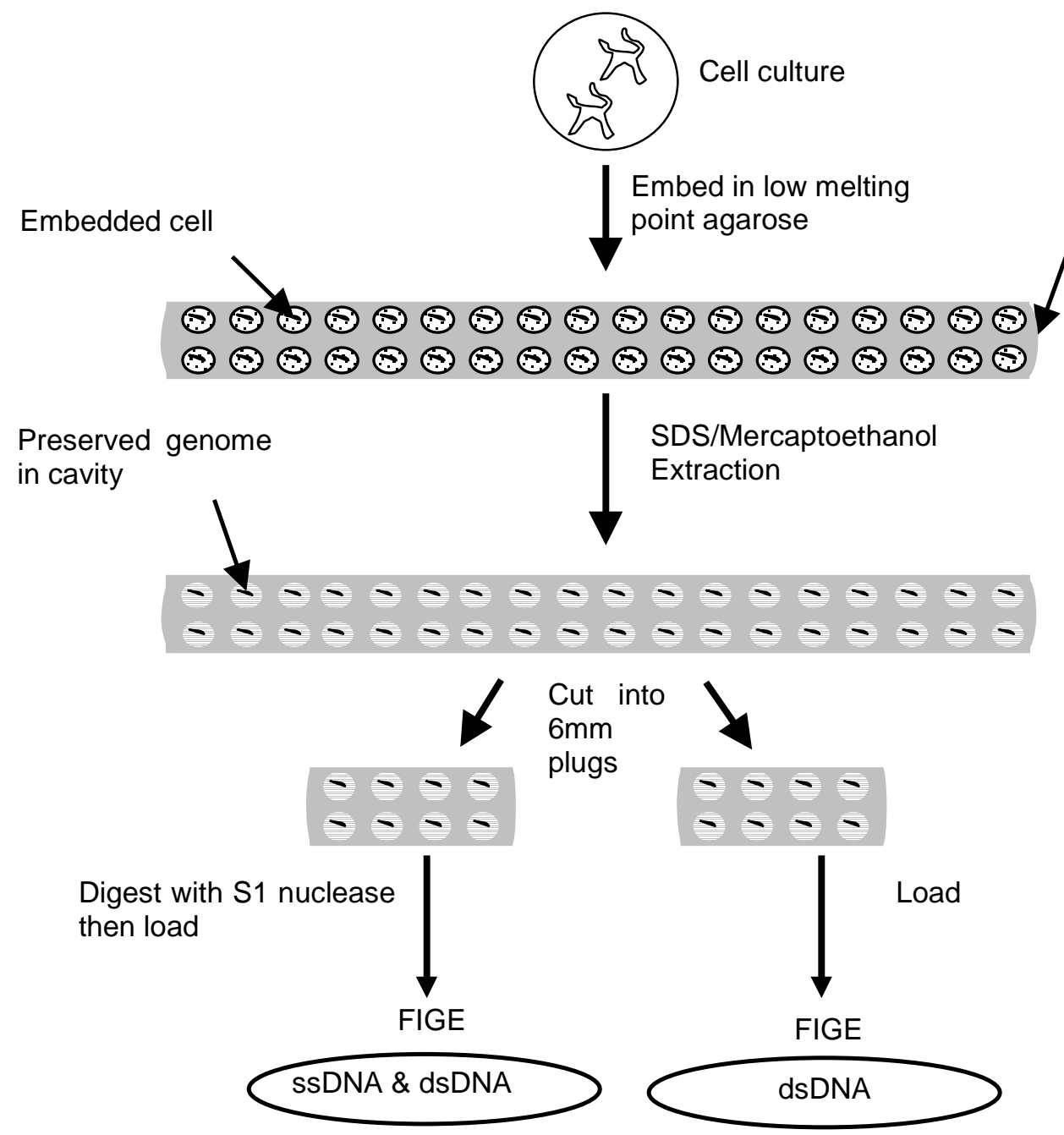

Figure 2. Schematic diagram of low melting point agarose embedding method. After treatment, cells are scraped and mixed with low melting point agarose before casting them, using $1 \mathrm{ml}$ syringe, into tygon tubing. The agarose rod containing the cells is purified from lipids and proteins and hence the genome is left relatively intact to be analyzed by field inversion gel electrophoresis (FIGE). The rod is cut into 6-mm plugs to fit snugly in the well of the gel. To determine the extent of double strand DNA fragmentation (dsDNA), plugs are directly loaded on the gel and FIGE is performed. ssDNA is assessed by digesting the plug with S1 endonuclease before running FIGE. 
$30^{\circ} \mathrm{C}$ followed by washing in TE twice for an h each. OL DNA content in the plugs was determined spectrophotmetrically at $\lambda=260 \mathrm{~nm}$ after melting, trituration, and appropriate dilution. One $\mathrm{OD}_{260}$ yields $50 \mu \mathrm{g} / \mathrm{ml}$ DNA. On average, one plug contained approximately $1.85 \mu \mathrm{g}$ of OL DNA and $4.0 \mu \mathrm{g}$ of C6 DNA. The larger amount of DNA for the same number of C6 cells indicated that those cells are polyploids.

\subsection{S1 NUCLEASE DIGESTION}

S1 nuclease recognizes a hydrolyzed phosphodiester bond in one strand of DNA and cleaves the bond on the opposite strand. S1 nuclease also digests RNA however, at a much lower affinity than nicks in double stranded DNA. Hence, S1 nuclease is used for the detection of single stranded fragmentation of DNA. The plugs were digested with 2 units of $\mathrm{S} 1$ nuclease in $0.2 \mathrm{ml} \mathrm{S} 1$ nuclease buffer for $2 \mathrm{~h}$ at $30^{\circ} \mathrm{C}$ prior to proteinase $\mathrm{K}$ digestion (vide supra). The reaction was stopped by soaking the plugs in $4^{\circ} \mathrm{C}$ cold TE buffer for 1 min and subsequent triple washing, one hour each in TE.

\subsection{FIELD INVERSION GEL ELECTROPHORESIS (FIGE)}

In agarose gel electrophoresis, negatively charged DNA molecules are pulled through a porous gel with the aid of an electric field. An agarose gel presents a DNA molecule with a set of pores of varying sizes. Small molecules pass easily through most pores and move rapidly through the gel. However, over a certain molecular weight, DNA molecules are hindered from sieving through and therefore are limited from migrating any further in the gel. DNA molecules greater than $40 \mathrm{~kb}$ reach their terminal velocity whereby no higher 
resolution can be obtained in conventional agarose gel electrophoresis. With the advent of pulse field gel electrophoresis (Cantor and Schwartz, 1984), it was shown that it is possible to resolve molecules that would otherwise run at limiting mobility by cyclically varying the orientation of the electric field in the gel during the run. Since DNA molecules squeeze through pores in an extended conformation, reversing the electric field will force DNA molecules to reorient themselves into a new head start in the gel. This way, large DNA molecules will need more time to reorient themselves and migrate in the reverse direction than smaller DNA molecules. By using this difference in reorientation time between large and small migrating DNA molecules, pulsating forward and reverse times in a ratio of 2:5:1 to 3:5:1 allows the separation of DNA molecules ranging in size from $4 \mathrm{~kb}$ to $2 \mathrm{Mbp}$. Schwartz and Cantor used a nonuniform electric field that produces crooked paths of DNA migrations. FIGE resolved this problem by using parallel electrodes thereby a uniform electric field can be reoriented by an angle of 180 degrees allowing for straight DNA lanes to be produced.

Six mm plugs were inserted into the wells of $1 \%$ pulse field certified agarose gels, and the DNA was analyzed by FIGE. A programmable power inverter PPI-200 (MJ Research, Watertown, MA) and program number 6 were used. Concatenated chromosome of lambda phage (multiples of $48.5 \mathrm{~kb}$ ) was used as a DNA size standard. Gels were stained with $350 \mathrm{ml}$ distilled water containing $10 \mu \mathrm{g} / \mathrm{ml}$ ethidium bromide (EtBr) for $20 \mathrm{~min}$ while gently agitating over a belly dancer (Stovall Life Science, Inc, Greensboro, NC). Gels were destained in the same volume and for the same amount of time with distilled water before visualizing the DNA using Stratagene Eagle eye II image analysis software. DNA 
quantitation within the gel was performed using fluoroImager SI/ImageQuaNT (Molecular Dynamics, Sunnyvale, CA) as well as SigmaGel 1.0 image analysis software (Jandel scientific software) and spectrophotometry at $260 \mathrm{~nm}$. DNA quantitation by spectrophotometry was performed after melting each plug in a $70^{\circ} \mathrm{C}$ water bath, adding 5 $\mathrm{mM}$ sodium hydroxide, triturating the DNA, and cooling down to room temperature.

\subsection{ISOLATION OF NUCLEI (Grubinska et al., 1994)}

C6 cells growing in serum-free medium were washed with nuclear isolation buffer then scraped using the same buffer before they were transferred into a $3 \mathrm{ml}$ polystyrene tube. Again, the dish was washed and scraped then the cells were combined with the previous scraping. Visual assessment under the light microscope showed that nearly all of the cells (>95\%) were collected. The cells are spun down at 2,500 rpm for $5 \mathrm{~min}$ (SJ13.1 rotor) then resuspended in $800 \mu \mathrm{l}$ of nuclear isolation buffer. Two gentle homogenizations (4 up-anddown strokes) were performed each for 1 min using $400 \mu \mathrm{l}$ of cell suspension and $400 \mu \mathrm{l}$ NP40/metrizamide. Nuclei were pelleted by centrifugation at 2,500 rpm for $5 \mathrm{~min}$. The nuclear pellet was resuspended in NI buffer, then $50 \mu \mathrm{l}$ of the suspension is counted on a hemocytometer using $50 \mu \mathrm{l}$ of methylene blue as the nuclear dye. The nuclei were centrifuged at 2,500 rpm for $5 \mathrm{~min}$ and resuspended in nuclear incubation buffer at a concentration of $1 \times 10^{6}$ per $25 \mu$ l. Nuclei were treated right after isolation. 


\section{RESULTS}

\subsection{Kinetics and extent of chromatin fragmentation}

Continuous exposure of OL to $1 \mathrm{mM} \mathrm{H}_{2} \mathrm{O}_{2}$ for up to $45 \mathrm{~min}$ had no detectable effect on cell morphology, or their viability as determined by trypan blue exclusion. However, the treatment induced a rapid fragmentation of nuclear chromatin as revealed by FIGE. To identify DNA fragments resulting from double stranded breaks, i.e., double stranded DNA (dsDNA) fragments, the plugs were directly subjected to FIGE. To detect fragments resulting from single stranded breaks, genomic DNA was digested with S1 endonuclease prior to electrophoretic separation. S1 endonuclease recognizes existing single stranded breaks, and cuts the opposite strand to produce distinct dsDNA fragments that can be resolved by FIGE. Consequently, fragments obtained after S1 digestion will be referred to as single stranded DNA (ssDNA) fragments. However, it should be noted that ssDNA gel bands might also contain small amounts of dsDNA fragments present in the samples before S1 digestion, and hence, represent a total of dsDNA and ssDNA fragments. All experiments were repeated at least four times, and the figures show representative gels. As seen from a representative gel in figure 7 , the digestion of nuclear chromatin into $>400 \mathrm{~kb}$ dsDNA fragments was evident $5 \mathrm{~min}$ after the exposure to $1 \mathrm{mM} \mathrm{H}_{2} \mathrm{O}_{2}$ (upper left panel), and after 40 min these fragments amounted to approximately $9 \%$ of the total genomic DNA as determined by fluoroimaging (lower panel). No significant digestion into 50-200 kb dsDNA fragments was evident. Single stranded break analysis of DNA from untreated OL revealed 
that approximately $10 \%$ of genomic DNA was present in ssDNA fragments $>400 \mathrm{~kb}$ (upper right panel and lower panel). Such "normal" fragmentation was also found in other untreated Exposure to $1 \mathrm{mM} \mathrm{H}_{2} \mathrm{O}_{2}$
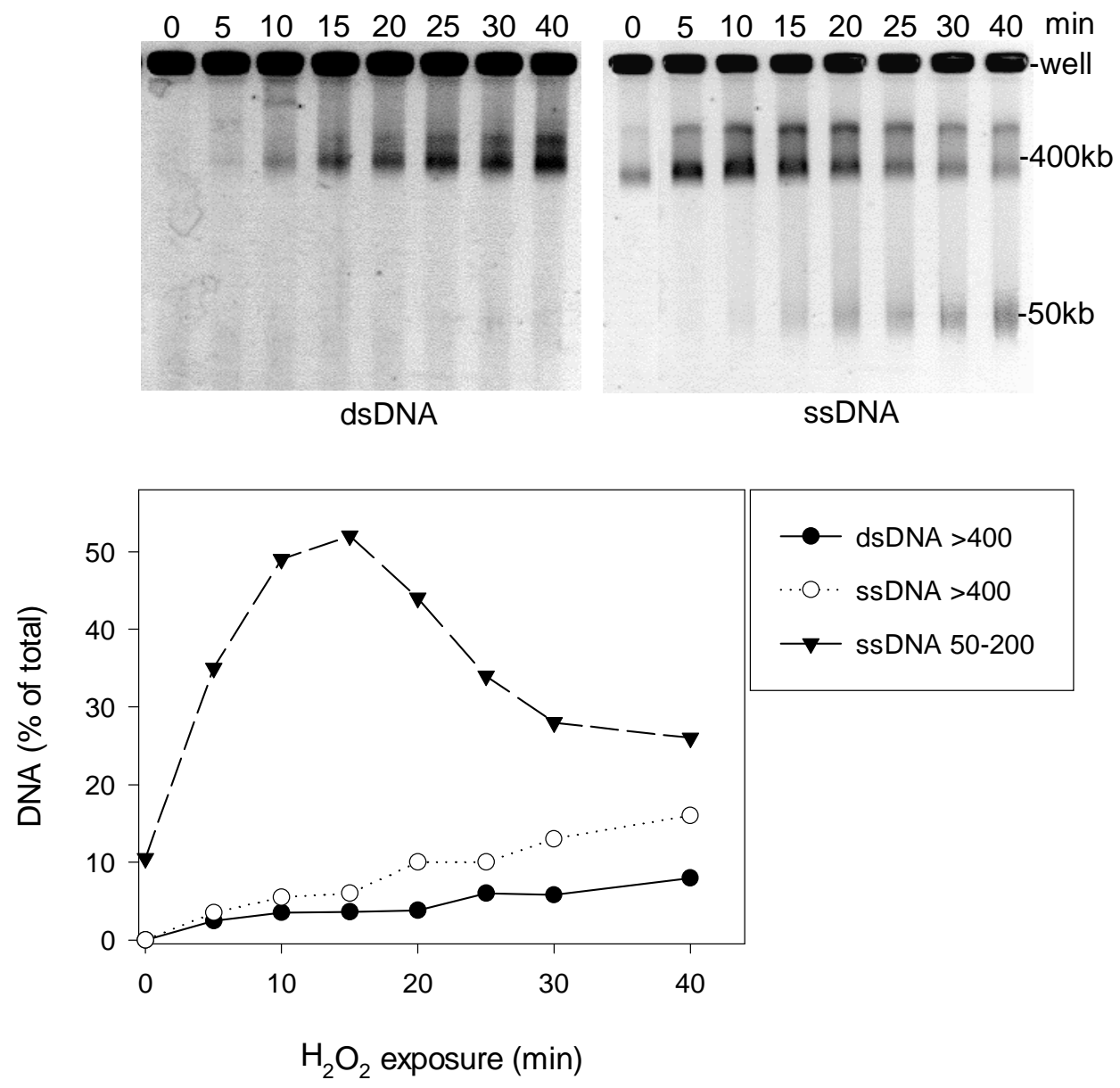

Figure 7. Rapid degradation of $\mathrm{OL}$ chromatin induced by $\mathrm{H}_{2} \mathrm{O}_{2}$. Cells were exposed to $1 \mathrm{mM} \mathrm{H}_{2} \mathrm{O}_{2}$ for various periods of time as indicated. The integrity of genomic DNA was analyzed by FIGE. Upper panel shows negative of EtBr stained gels. The embedded DNA was subjected to FIGE before (dsDNA gel), or after (ssDNA gel) S1 digestion. In this and subsequent experiments, two agarose plugs were used per well in dsDNA gels, whereas only one plug was used in ssDNA gels. Also, note that gel pictures were individually contrast adjusted to provide the best visualization of bands. Consequently, band intensities can only be compared within the same gel. Lower panel shows the distribution of DNA throughout the gels (including the wells) quantitated by fluoroimaging. The values are expressed as percentage of the total DNA per lane. 
cells (Walker et al, 1997), and is likely to result from the scission at certain AT-rich MARs, which feature ssDNA and/or secondary DNA structures that are S1 sensitive (Bode et al, 1992). The exposure of cells to $\mathrm{H}_{2} \mathrm{O}_{2}$ resulted in a precipitous increase in these fragments, and approximately half of the total genomic DNA was fragmented within 10 min (lower panel). Also, a small amount of ssDNA fragments of approximately 50-200 kb was produced. After $15 \mathrm{~min},>400 \mathrm{~kb}$ fragments began to decrease concomitantly with the increase of 50-200 kb fragments, indicating a consecutive digestion within this chromatin pool. The amount of ssDNA fragments of both $>400 \mathrm{~kb}$ and $50-200 \mathrm{~kb}$ variety was always much higher than the amount of dsDNA fragments indicating that the DNA digestion was propagated through a single strand scission, and that the bifilar fragmentation resulted from the accumulation of single stranded breaks. This is in agreement with the single strand scission mechanism found in other cellular systems (Peitch et al, 1993; Walker et al, 1997). The size of the chromatin pool undergoing rapid ssDNA digestion was further confirmed by spectrophotometric quantitation of DNA in agarose plugs (Table 1).

Table 1

The size of nuclear chromatin pool undergoing rapid fragmentation induced by $\mathrm{H}_{2} \mathrm{O}_{2}{ }^{a}$.

\begin{tabular}{|c|c|c|c|}
\hline \multirow[t]{2}{*}{$\begin{array}{l}\mathrm{H}_{2} \mathrm{O}_{2} \text { treatment } \\
(\mathrm{min})\end{array}$} & \multicolumn{2}{|c|}{$\begin{array}{l}\text { DNA content } \\
\text { ( } \mu \mathrm{g} / \text { plug })\end{array}$} & \multirow[t]{2}{*}{$\begin{array}{c}\text { Digested DNA } \\
(\%)\end{array}$} \\
\hline & Before FIGE & After FIGE & \\
\hline $\begin{array}{l}0 \\
15\end{array}$ & $\begin{array}{l}1.91 \pm 0.28 \\
1.80 \pm 0.38\end{array}$ & $\begin{array}{l}1.70 \pm 0.33 \\
1.02 \pm 0.36\end{array}$ & $\begin{array}{l}11 \pm 5 \\
45 \pm 8\end{array}$ \\
\hline
\end{tabular}


In this paradigm, the difference between the amount of DNA in plugs before FIGE and after FIGE represents the amount of fragmented DNA that was transferred from the plugs into the gel. The analysis showed that $11 \%$ of total genomic DNA in untreated OL was in the form of ssDNA fragments. After $15 \mathrm{~min}$ of treatment with $1 \mathrm{mM} \mathrm{H}_{2} \mathrm{O}_{2}$, this value increased to $45 \%$, which represents the digestible pool of nuclear chromatin.

\section{2 $\underline{\mathrm{H}}_{2} \underline{\mathrm{O}}_{2} \underline{\text { concentration dependence }}$}

Detectable dsDNA > $400 \mathrm{~kb}$ fragmentation could be elicited within $15 \mathrm{~min}$ by exposure to $0.05 \mathrm{mM} \mathrm{H}_{2} \mathrm{O}_{2}$ (fig.8). The fragmentation increased with $\mathrm{H}_{2} \mathrm{O}_{2}$ concentration, and plateaued at $0.5 \mathrm{mM}$. Also, ssDNA >400 kb fragmentation above the control base-line was clearly evident at $0.05 \mathrm{mM} \mathrm{H}_{2} \mathrm{O}_{2}$, and at $0.1 \mathrm{mM} \mathrm{H}_{2} \mathrm{O}_{2}$, chromatin was further digested to $50-200 \mathrm{~kb}$ fragments. The maximal $50-200 \mathrm{~kb}$ fragmentation was achieved at $0.25 \mathrm{mM}$ $\mathrm{H}_{2} \mathrm{O}_{2}$.

15 min exposure to $\mathrm{H}_{2} \mathrm{O}_{2}$

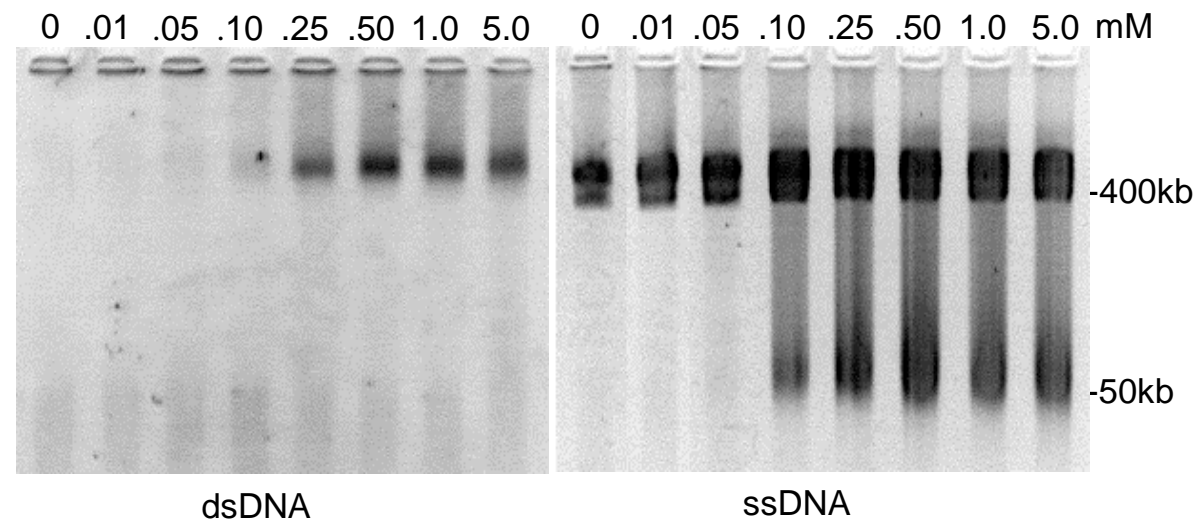

Figure 8. Fragmentation of $\mathrm{OL}$ chromatin induced by various $\mathrm{H}_{2} \mathrm{O}_{2}$ concentrations. Cells were exposed for 15 min to various concentrations of $\mathrm{H}_{2} \mathrm{O}_{2}$ as indicated. The integrity of genomic DNA was analyzed by FIGE. The picture shows negatives of EtBr stained gels. In this gel plugs have been removed from the wells. The embedded DNA was subjected to FIGE before (dsDNA gel), or after (ssDNA gel) S1 digestion. In the gels shown here, the plugs have been removed. 


\subsection{Reversibility}

The rapid fragmentation occurring during $15 \mathrm{~min}$ of exposure to $1 \mathrm{mM} \mathrm{H}_{2} \mathrm{O}_{2}$ was partly reversible (fig.9). Hence, when the cells were allowed to recover in normal medium for $2 \mathrm{~h}$, the amount of $>400 \mathrm{~kb}$ fragments decreased profoundly. This effect was evident in the case of both ssDNA and dsDNA fragmentation. Subsequently, the amount of $>400$

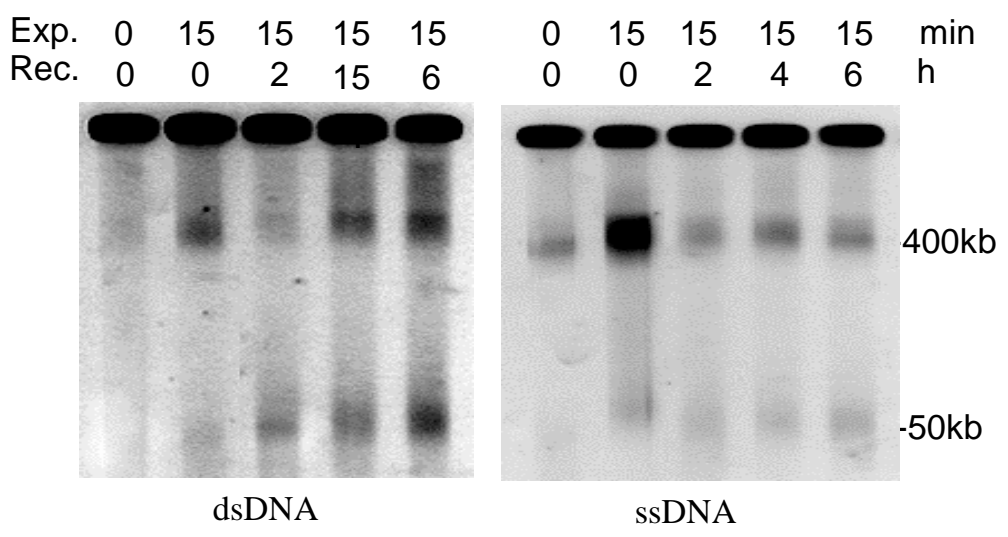

Figure 9. Transient decrease in $400 \mathrm{~kb}$ fragments during recovery of $\mathrm{H}_{2} \mathrm{O}_{2}$-treated $\mathrm{OL}$. Cells were exposed to $1 \mathrm{mM}$ for $15 \mathrm{~min}$ (Exp.), and allowed to recover (Rec.) for up to $6 \mathrm{~h}$. The integrity of genomic DNA was analyzed by FIGE. The picture shows negatives of EtBr stained gels. The embedded DNA was subjected to FIGE before (dsDNA gel), or after (ssDNA gel) S1 digestion.

fragments gradually increased. On the other hand, there was no transient decrease in 50-200 $\mathrm{kb}$ fragments during the recovery period. The amount of both ssDNA and dsDNA 50-200 kb fragments increased steadily from 0 to $6 \mathrm{~h}$ of recovery. Hence, the results show that although the cells mount a massive "repair" response during the early recovery period resulting in the religation of $>400$ fragments, the "repair" process is gradually attenuated, probably by ensuing damage to other cellular elements, and ultimately chromatin digestion prevails. 


\subsection{Intracellular calcium is required for HOCD}

To test the involvement of calcium in HOCD, we sequestered intracellular calcium with BAPTA/AM prior to challenging oligodendrocytes with $\mathrm{H}_{2} \mathrm{O}_{2}$. BAPTA/AM, a cell membrane permeable compound is modified by intracellular esterases to yield a highly potent and specific calcium chelator, BAPTA, that is trapped within the cells. As shown in figure 10, the pretreatment of oligodendrocytes with BAPTA/AM efficiently attenuated $\mathrm{H}_{2} \mathrm{O}_{2}$-induced HOCD in oligodendrocytes in a concentration-dependent fashion, strongly indicating the role of calcium in the process. Both, the initial digestion into $\geq 400 \mathrm{~kb}$ ssDNA fragments, and the subsequent digestion into $\geq 400 \mathrm{dsDNA}$ and $50-200 \mathrm{~kb}$ ssDNA fragments were inhibited. Total inhibition of chromatin digestion was observed at $50 \mu \mathrm{M}$ BAPTA/AM. Interestingly, even $\geq$ $400 \mathrm{~kb}$ ssDNA fragments normally present in untreated cells disappeared in BAPTA/AMpretreated cells. Depleting iron with desferrioxamine mesylate (DFOM), a membrane permeable iron-specific chelator has been shown to abrogate $\mathrm{H}_{2} \mathrm{O}_{2}$-induced rise in intracellular calcium concentration, and attenuate DNA nicking in renal cells (Golconda et al, 1993). We used this paradigm and showed that DFOM also attenuated $\mathrm{H}_{2} \mathrm{O}_{2}$-induced $\mathrm{HOCD}$ in oligodendrocytes (fig.11). Like BABTA/AM, DFOM efficiently inhibited chromatin digestion into $\geq 400 \mathrm{~kb}$ dsDNA and 50-200 kb ssDNA fragments in a concentration-dependent manner (fig.11). However, in contrast to BABTA/AM pretreatment, the pretreatment of cells with DFOM increased $\geq 400 \mathrm{~kb}$ ssDNA fragments as compared to cells treated with $\mathrm{H}_{2} \mathrm{O}_{2}$ alone. We have previously shown (Mouzannar et al, 2001) that the $\geq 400 \mathrm{~kb}$ ssDNA fragments undergo transient accumulation that peaks at 10-15 $\min$ of $\mathrm{H}_{2} \mathrm{O}_{2}$ exposure, and then rapidly declines due to subsequent digestion. Therefore, the increase of $\geq 400 \mathrm{~kb}$ ssDNA fragments in DFOM- 
pretreated cells can be attributed to the lack of DFOM effect on $\geq 400 \mathrm{~kb}$ ssDNA digestion, and DFOM-induced inhibition of subsequent digestion.

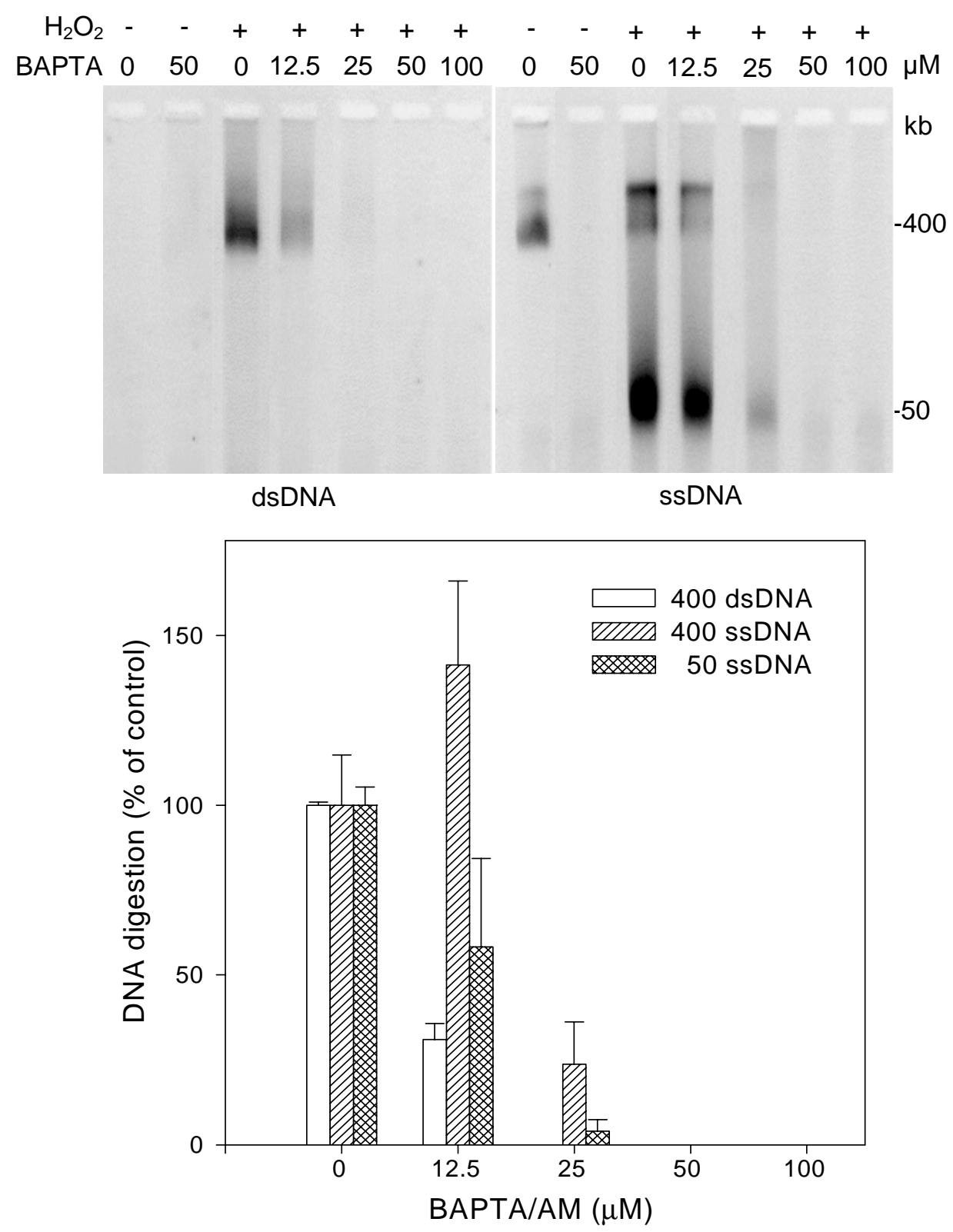

Figure 10. The inhibition of $\mathrm{H}_{2} \mathrm{O}_{2}$-induced $\mathrm{HOCD}$ in cultured oligodendrocytes by BAPTA/AM. The cells were pretreated for 30 min with different concentrations of BABTA/AM and subsequently treated with 1 $m \mathrm{M} \mathrm{H}_{2} \mathrm{O}_{2}$ for $30 \mathrm{~min}$. The digestion of genomic DNA was assessed by FIGE. Upper panel shows negatives of representative gels stained with EtBr. In dsDNA gel, the genomic DNA was directly resolved by FIGE. In SsDNA gel, genomic DNA was digested with $S 1$ endonuclease prior to FIGE to detect single stranded fragments. Lower panel shows the inhibition of $\mathrm{H}_{2} \mathrm{O}_{2}$-induced $\mathrm{HOCD}$ as a function of BAPTA/AM concentration. The inhibition is expressed as per cent of chromatin digestion in cells treated with $\mathrm{H}_{2} \mathrm{O}_{2}$ only (control). The values represent means $\pm S$.Ds. calculated from four independent experiments. 

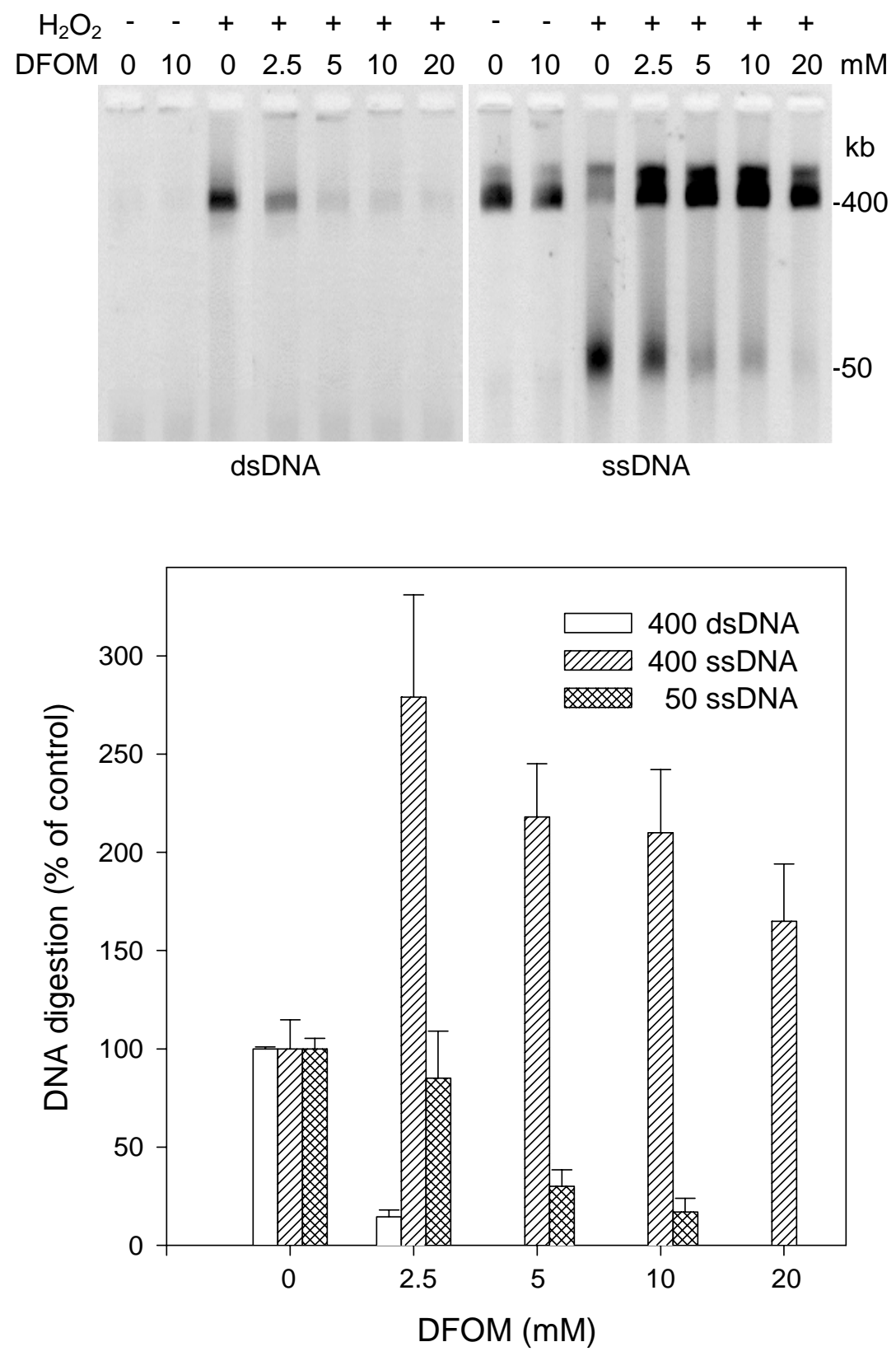

Figure 11. The inhibition of $\mathrm{H}_{2} \mathrm{O}_{2}$-induced $\mathrm{HOCD}$ in cultured oligodendrocytes by DFOM. The cells were pretreated for 30 min with different concentrations of DFOM and subsequently treated with $1 \mathrm{mM} \mathrm{H}_{2} \mathrm{O}_{2}$ for $30 \mathrm{~min}$. The digestion of genomic DNA was assessed by FIGE. Upper panel shows negatives of representative gels stained with EtBr. In dsDNA gel, the genomic DNA was directly resolved by FIGE. In ssDNA gel, genomic DNA was digested with S1 endonuclease prior to FIGE to detect single stranded fragments. Lower panel shows the inhibition of $\mathrm{H}_{2} \mathrm{O}_{2}$-induced $\mathrm{HOCD}$ as a function of DFOM concentration. The inhibition is expressed as per cent of chromatin digestion in cells treated with $\mathrm{H}_{2} \mathrm{O}_{2}$ only (control). The values represent means \pm S.D calculated from four independent experiments. 


\section{5. $\mathrm{HOCD}$ is not induced by intracellular calcium increase}

In contrast to the profound effect of BAPTA/AM (fig.10), neither removing extracellular calcium (fig.12A) nor blocking the release of calcium from intracellular stores with a specific inhibitor, TMB-8 (fig.12B), attenuated $\mathrm{H}_{2} \mathrm{O}_{2}$-induced HOCD. Consequently, although calcium is needed for the $\mathrm{H}_{2} \mathrm{O}_{2}$-induced activation of MAR-associated endonuclease, an increase in the free intracellular calcium concentration by itself may not be sufficient to activate the enzyme. Figure $12 \mathrm{C}$ supports this contention as the treatment of oligodendrocytes with A23187 calcium ionophore, which has been shown to induce a rapid and massive elevation of free intracellular calcium in oligodendrocytes (Benjamins \& Nedelkoska, 1996), failed to elicit chromatin fragmentation (fig.12C).

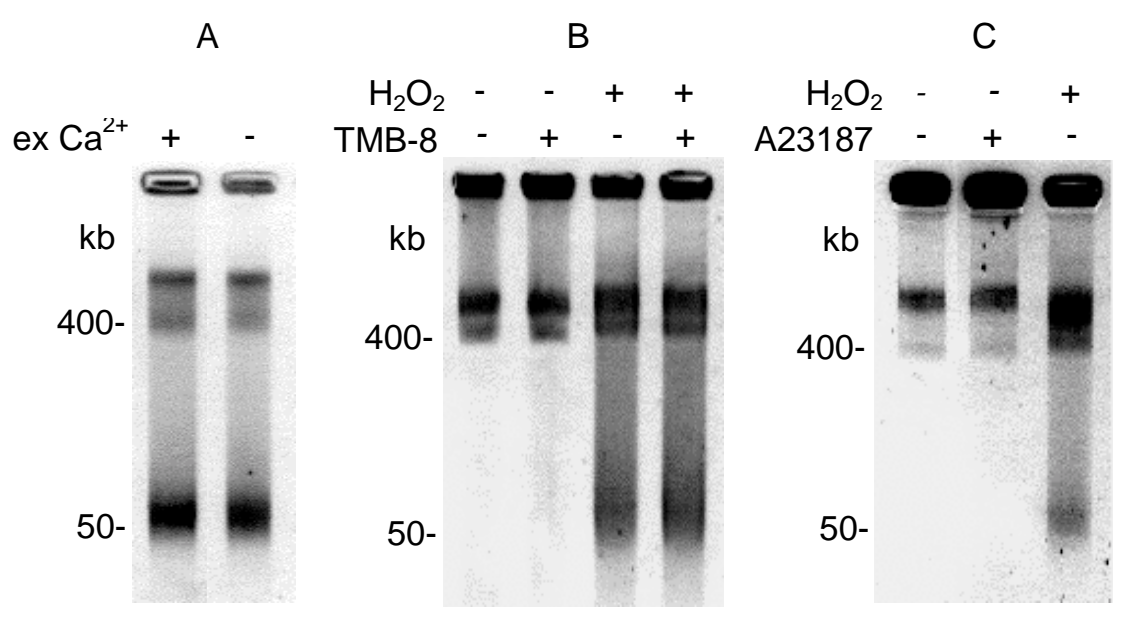

Figure 12. The effects of extracellular calcium, TMB-8, and A23187 ionophore on HOCD in cultured oligodendrocytes. In panel $A$, the cells were exposed to $1 \mathrm{mM} \mathrm{H}_{2} \mathrm{O}_{2}$ for 30 min either in $\mathrm{BSS}$ containing $1.7 \mathrm{mM} \mathrm{CaCl}_{2}(+)$ or in calcium-free BSS (-). In panel B, the cells were pretreated with $0.1 \mathrm{mM} \mathrm{TMB-8 \text {for }}$ $30 \mathrm{~min}$ to inhibit the mobilization of $\mathrm{Ca}^{2+}$ from intracellular stores, and subsequently exposed to $1 \mathrm{mM}$ $\mathrm{H}_{2} \mathrm{O}_{2}$ for $15 \mathrm{~min}$, as indicated. In panel $\mathrm{C}$, the cells were incubated for 15 min with either $5 \mu M$ A23187 ionophore to induce calcium influx into the cells, or with $1 \mathrm{mM} \mathrm{H}_{2} \mathrm{O}_{2}$, as indicated. The DNA was digested with $S 1$ endonuclease to visualize single stranded breaks, and analyzed by FIGE. The pictures show negatives of representative gels stained with EtBr. 


\subsection{Matrix attachment region-associated endonuclease is calcium-independent but}

\section{magnesium-dependent}

To further resolve the involvement of calcium in HOCD, subsequent experiments were performed in purified nuclei. Because of the paucity of cultured oligodendrocytes, we used rat glioma C6 cells, which have been used extensively as oligodendrocyte models. We have also shown that the kinetics of $\mathrm{H}_{2} \mathrm{O}_{2}$-induced $\mathrm{HOCD}$ (fig.7 \& 13) and the inhibition pattern by BAPTA/AM (fig.10 \& 14) and DFOM (fig.11 \& 15) are virtually the same in C6 cells and oligodendrocytes.

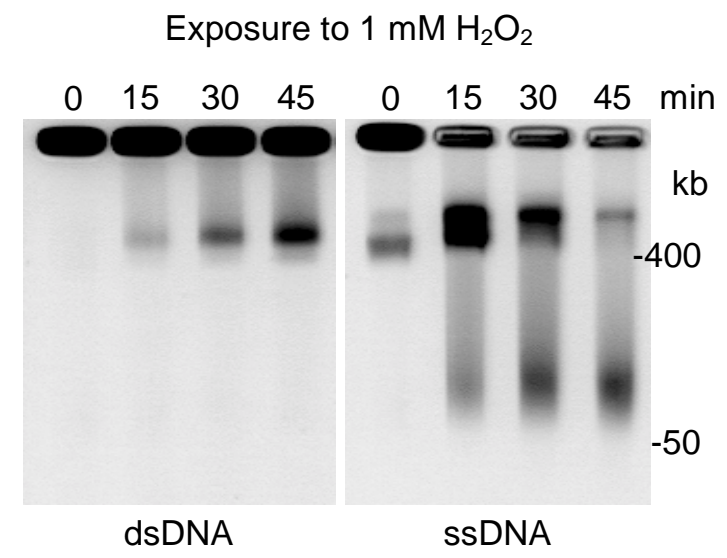

Figure 13. Rapid degradation of $\mathrm{C} 6$ cells chromatin induced by $\mathrm{H}_{2} \mathrm{O}_{2}$. Cells were exposed to $1 \mathrm{mM}$ $\mathrm{H}_{2} \mathrm{O}_{2}$ for 15,30 and $45 \mathrm{~min}$. The embedded DNA was subjected to FIGE before (dsDNA gel), or after (ssDNA gel) S1 digestion. Pictures show negative of EtBr stained gels. 
C6 cells
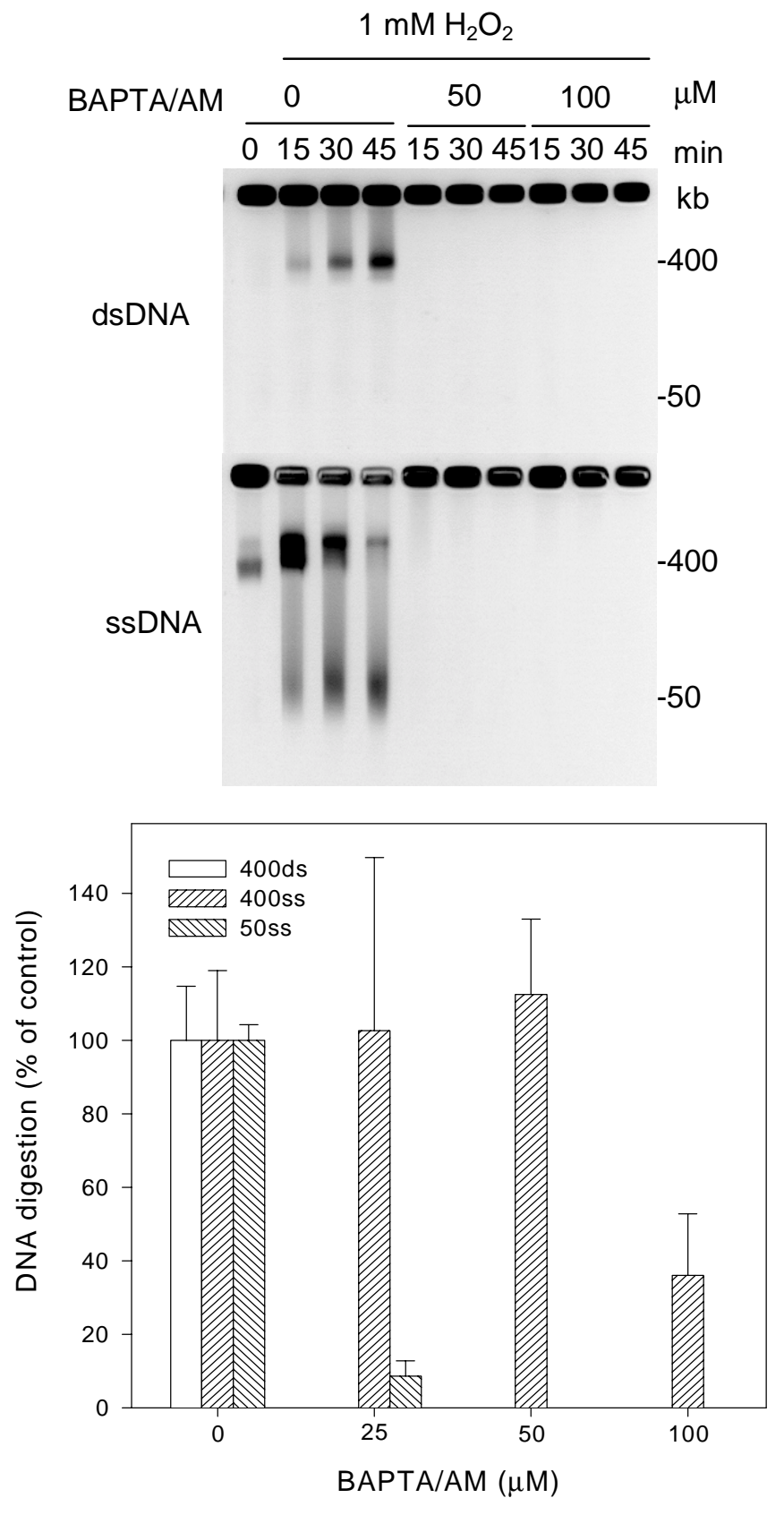

Figure 14. The inhibition of $\mathrm{H}_{2} \mathrm{O}_{2}$-induced $\mathrm{HOCD}$ in $\mathrm{C} 6$ cells by BAPTA/AM. The cells were pretreated for 30 min with different concentrations of BABTA/AM and subsequently treated with $1 \mathrm{mM} \mathrm{H}_{2} \mathrm{O}_{2}$ for 30 min. The digestion of genomic DNA was assessed by FIGE. Upper panel shows negatives of representative gels stained with EtBr. In dsDNA gel, the genomic DNA was directly resolved by FIGE. In SSDNA gel, genomic DNA was digested with $S 1$ endonuclease prior to FIGE to detect single stranded fragments. Lower panel shows the inhibition of $\mathrm{H}_{2} \mathrm{O}_{2}$-induced $\mathrm{HOCD}$ as a function of BAPTA/AM concentration. The inhibition is expressed as per cent of chromatin digestion in cells treated with $\mathrm{H}_{2} \mathrm{O}_{2}$ only (control). The values represent means $\pm S$.Ds. calculated from four independent experiments. 
C6 cells
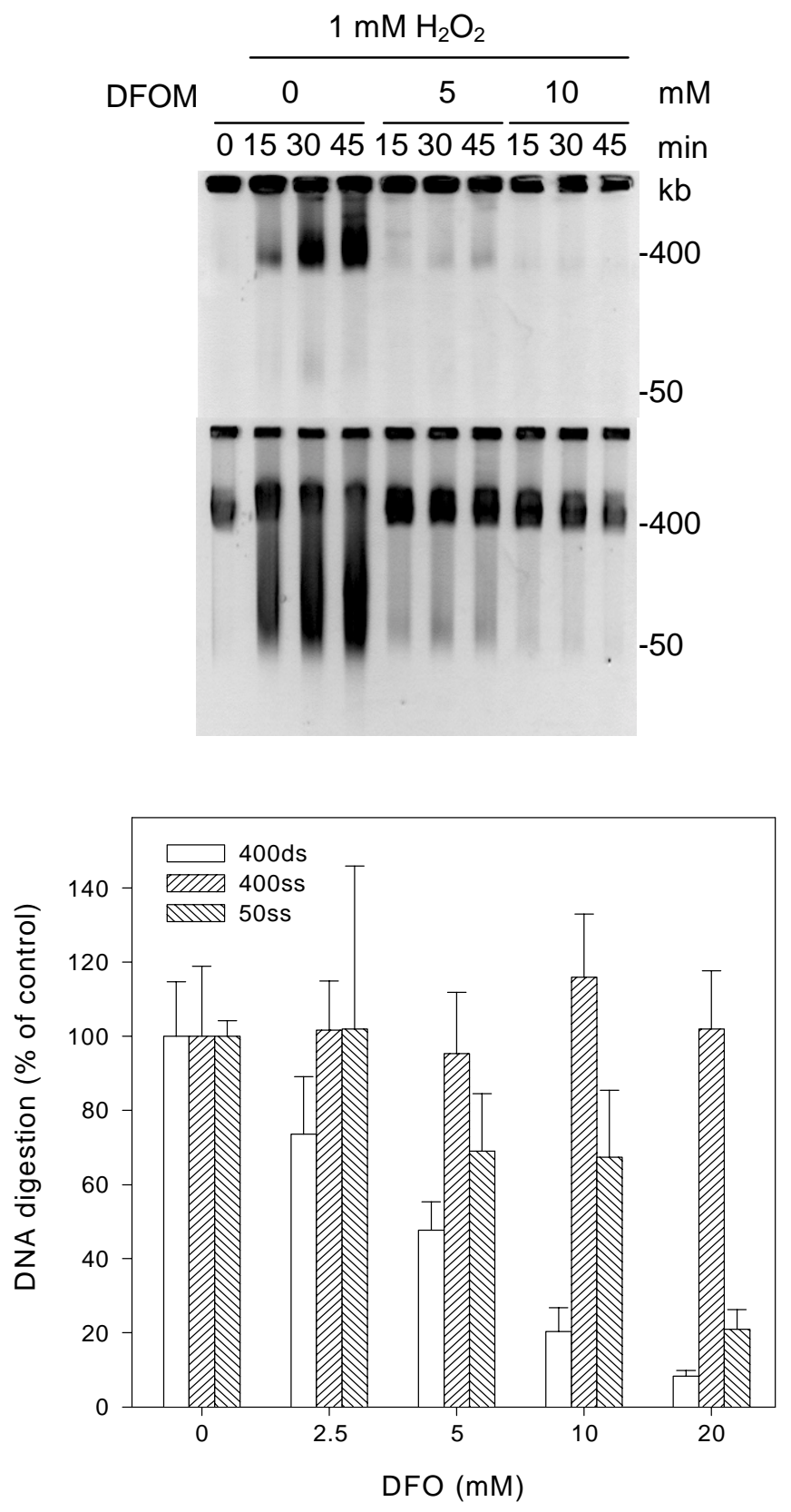

Figure 15. The inhibition of $\mathrm{H}_{2} \mathrm{O}_{2}$-induced $\mathrm{HOCD}$ in $\mathrm{C} 6$ cells by DFOM. The cells were pretreated for 30 min with different concentrations of DFOM and subsequently treated with $1 \mathrm{mM} \mathrm{H}_{2} \mathrm{O}_{2}$ for 30 min. The digestion of genomic DNA was assessed by FIGE. Upper panel shows negatives of representative gels stained with EtBr. In dsDNA gel, the genomic DNA was directly resolved by FIGE. In SsDNA gel, genomic DNA was digested with $S 1$ endonuclease prior to FIGE to detect single stranded fragments. Lower panel shows the inhibition of $\mathrm{H}_{2} \mathrm{O}_{2}$-induced $\mathrm{HOCD}$ as a function of DFOM concentration. The inhibition is expressed as per cent of chromatin digestion in cells treated with $\mathrm{H}_{2} \mathrm{O}_{2}$ only (control). The values represent means \pm S.D calculated from four independent experiments. 
The initial analysis presented in figure 16 showed that $\mathrm{H}_{2} \mathrm{O}_{2}$ by itself did not elicit HOCD indicating that the oxidant exerts its effect on chromatin indirectly through triggering signaling cascades that activate MAR-associated endonuclease.

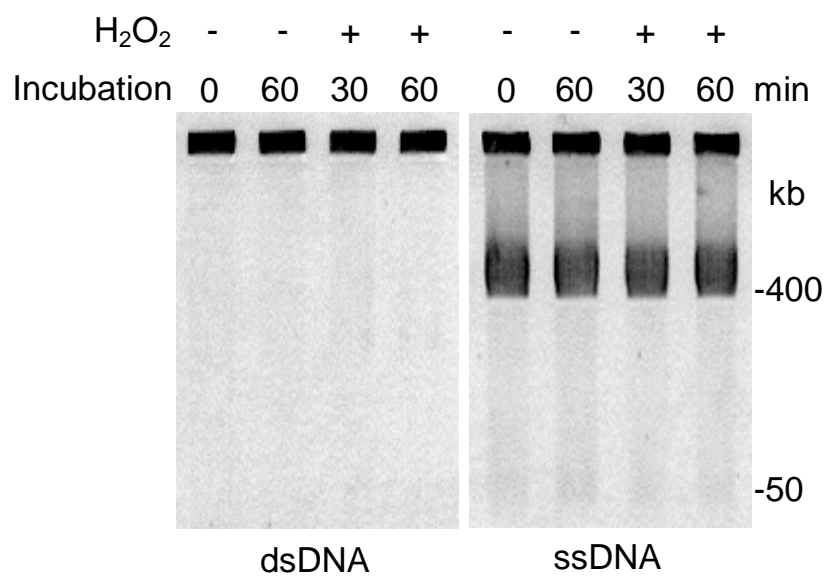

Figure 16. The effect of $\mathrm{H}_{2} \mathrm{O}_{2}$ on chromatin digestion in purified nuclei. Nuclei $\left(10^{6}\right)$ isolated from C6 cells were incubated in $50 \mu$ l of INC buffer (see Materials and Methods) in the presence of $1 \mathrm{mM} \mathrm{H}_{2} \mathrm{O}_{2}$ at $37^{\circ} \mathrm{C}$ for various periods of time, as indicated. The digestion of genomic DNA was assessed by FIGE. In dsDNA gel, the genomic DNA was directly resolved by FIGE. In SSDNA gel, genomic DNA was digested with S1 endonuclease prior to FIGE to detect single strand fragments. The pictures show negatives of representative gels stained with EtBr.

This endonuclease was subsequently shown to be calcium-independent, as even relatively high concentration of calcium $(100 \mu \mathrm{M})$ did not elicit HOCD (fig.17). However, the incubation of nuclei in the presence of magnesium (fig.17 \& 18) resulted in a profound $\mathrm{HOCD}$ in the pattern observed in $\mathrm{H}_{2} \mathrm{O}_{2}$-treated cells (fig. 10 \& 11), i.e., yielding both $\geq 400$ and 50-200 kb fragment populations. These results are in concordance with ion-dependence observed in thymocyte nuclei (Sun \& Cohen, 1994). Magnesium-induced chromatin digestion proceeded through a single strand scission mechanism as seen from the fact that the amount of single stranded fragments was always greater than the amount of double stranded 
fragments. Also, magnesium-induced chromatin digestion was not promoted by calcium (compare $0.5 \mathrm{mM} \mathrm{Mg}^{2+}$ without and with $100 \mu \mathrm{M} \mathrm{Ca}^{2+}$ in figure 17 ).

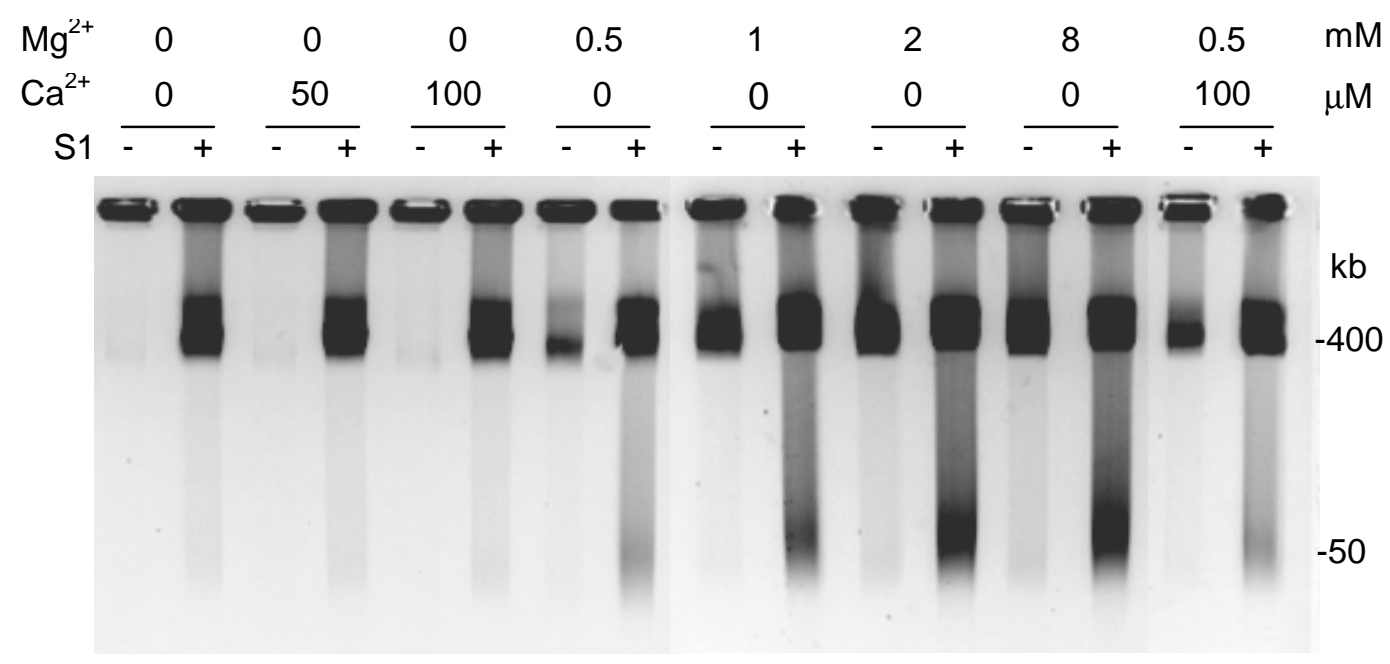

Figure 17. The effect of calcium and magnesium on chromatin digestion in purified nuclei. Nuclei $\left(10^{6}\right)$ isolated from C6 cells were incubated at $37^{\circ} \mathrm{C}$ in $50 \mu$ of INC buffer (see Materials and Methods) in the presence of various amounts of $\mathrm{CaCl}_{2}$ or $\mathrm{MgCl}_{2}$, as indicated. The digestion of genomic DNA was assessed by FIGE. To detect single stranded fragments genomic DNA was digested wit $h$ S1 endonuclease prior to FIGE. Single stranded fragmentation is shown in S1+ samples, whereas double stranded fragmentation is shown in S1-samples. The pictures show negatives of representative gels stained with EtBr. Incubation time ( $\mathrm{min})$

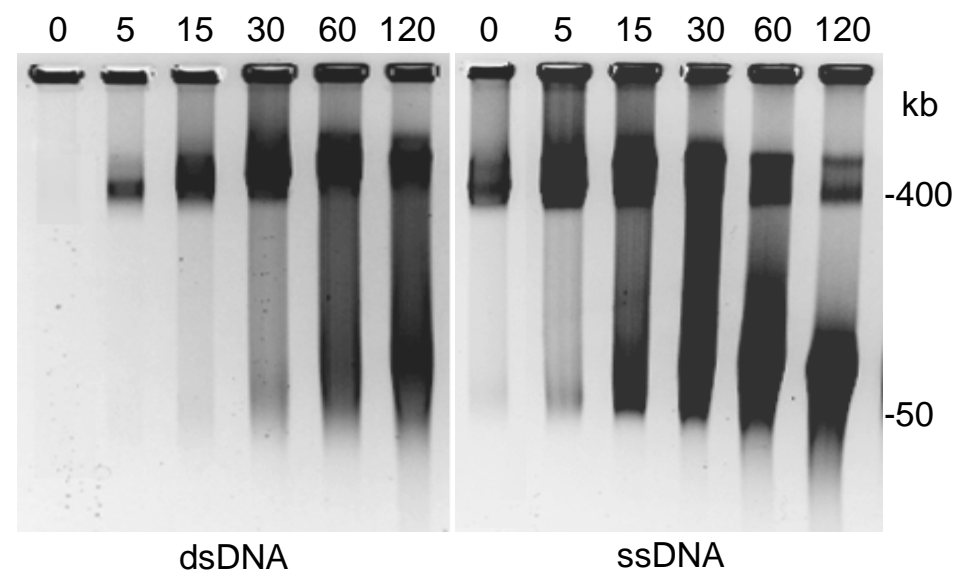

Figure 18. Time course of magnesium-induced chromatin digestion in purified nuclei. Nuclei $\left(10^{6}\right)$ isolated from C6 cells were incubated in $50 \mu$ of INC buffer (see Materials and Methods) in the presence of $4 \mathrm{mM}$ $\mathrm{MgCl}_{2}$ at $37^{\circ} \mathrm{C}$ for various periods of time, as indicated. The digestion of genomic DNA was assessed by FIGE. To detect single stranded fragments genomic DNA was digested with S1 endonuclease prior to FIGE. Single stranded fragmentation is shown in S1+ samples, whereas double stranded fragmentation is shown in S1-samples. The pictures show negatives of representative gels stained with EtBr. 


\subsection{Intracellular calcium depletion inactivates MAR-associated endonuclease}

The inhibition of $\mathrm{H}_{2} \mathrm{O}_{2}$-induced HOCD by BAPTA/AM (fig.10), and the inability of calcium to induce chromatin digestion in isolated nuclei (fig.12), indicated that the depletion of intracellular calcium during the pretreatment of cells with BAPTA/AM inactivates MARassociated endonuclease. The results shown in figure 19 favor this possibility as magnesiuminduced chromatin digestion in nuclei isolated from BAPTA/AM-treated cells was profoundly attenuated in comparison to nuclei from untreated (control) cells. Quantitative analysis from five independent experiments showed that in nuclei from BAPTA/AM-treated cells, chromatin digestion into $\geq 400 \mathrm{~kb}$ ssDNA, $\geq 400 \mathrm{~kb}$ dsDNA, 50-200 kb ssDNA and 50$200 \mathrm{~kb}$ dsDNA fragments was reduced respectively to $14 \pm 4,14 \pm 8,20 \pm 3$ and $28 \pm 7 \%$ of the

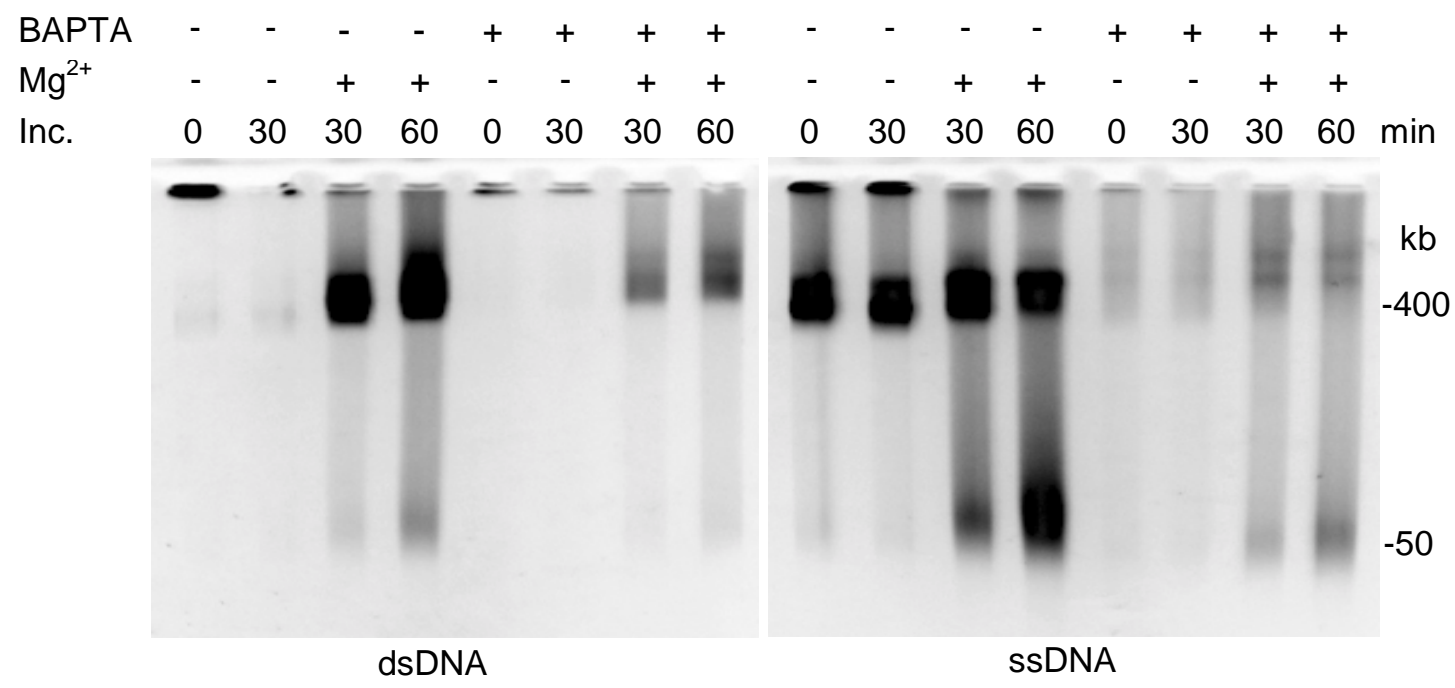

Figure 13. The effect of BABTA/AM pretreatment on magnesium-induced HOCD in C6 cells nuclei. C6 cells were treated with $50 \mu \mathrm{M} B A B T A / A M$ for 30 min before the isolation of nuclei (BABTA+). In parallel, nuclei were isolated from sister cultures without BAPTA/AM treatment (BAPTA-). Purified nuclei $\left(10^{6}\right.$ ) were incubated for various periods of time in $50 \mu \mathrm{l}$ of INC buffer (See Materials and Methods) at $37^{\circ} \mathrm{C}$ in the presence of magnesium $\left(\mathrm{Mg}^{2+}\right)$ or in the absence $\left(\mathrm{Mg}^{2-}\right)$ of $4 \mathrm{mM} \mathrm{MgCl}$. The digestion of genomic DNA was assessed by FIGE. In dsDNA gel, the genomic DNA was directly resolved by FIGE. In SSDNA gel, genomic DNA was digested with $S 1$ endonuclease to detect single stranded fragments. The picture shows negatives of representative gels stained with EtBr. 
value in nuclei from untreated cells. The amount of $\geq 400$ ssDNA fragments in unincubated nuclei isolated from BAPTA/AM-treated cells was reduced to $6 \pm 2 \%$ of the amount found in nuclei isolated from untreated cells. However, the chelation of calcium with EGTA after the isolation of nuclei failed to attenuate magnesium-induced chromatin digestion (fig.20) indicating that intact cellular structure is required for the inactivation of endonuclease by calcium depletion.

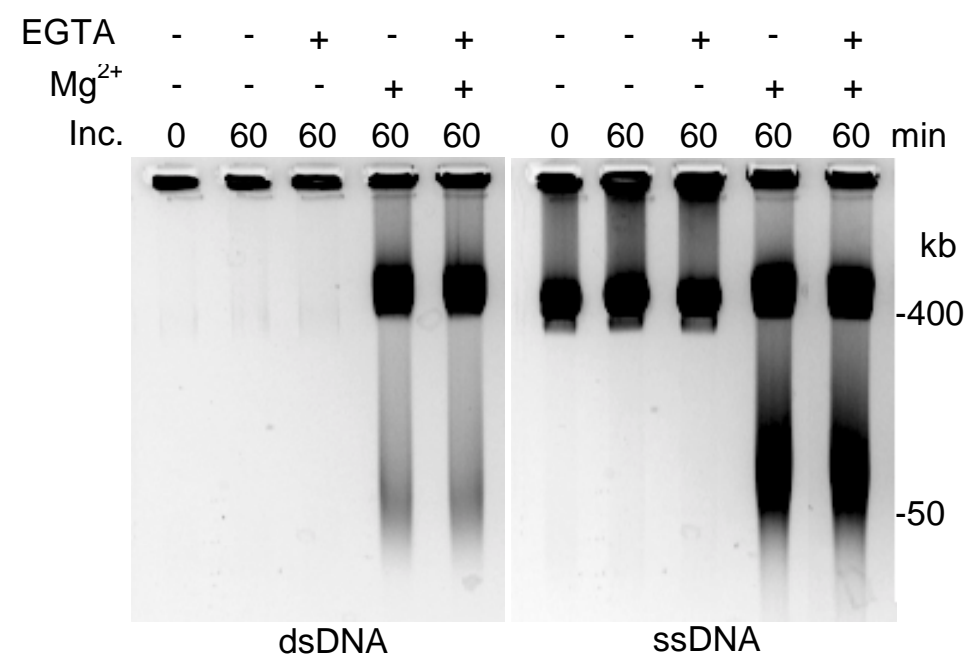

Figure 20. The effect of EGTA chelation on magnesium-induced chromatin digestion in C6 cell nuclei. Nuclei $\left(10^{6}\right)$ isolated from C6 cells were suspended in $50 \mu$ l of INC buffer (see Materials and Methods), and preincubated with (EGTA+) or without (EGTA-) $0.5 \mathrm{mM}$ ETGTA. Subsequently, the nuclei were incubated at $37^{\circ} \mathrm{C}$ in the presence $\left(\mathrm{Mg}^{2+}+\right)$ or in the absence $\left(\mathrm{Mg}^{2+}-\right)$ of $4 \mathrm{mM} \mathrm{MgCl}_{2}$ for various periods of time, as indicated. The digestion of genomic DNA was assessed by FIGE. In dsDNA gel, the genomic DNA was directly resolved by FIGE. In ssDNA gel, genomic DNA was digested with S1 endonuclease prior to FIGE to detect single stranded fragments. The pictures show negatives of representative gels stained with EtBr. 


\section{DISCUSSION}

Both the pattern of HMW chromatin fragmentation, and its propagation by single strand mechanism is in concordance with that observed in other cellular systems (Oberhammer et al, 1993b; Peitch et al, 1993; Cohen et al, 1994; Lagarkova et al, 1995; Beere et al, 1996; Walker et al, 1995, 1997). However, the use of short pulse exposures to $\mathrm{H}_{2} \mathrm{O}_{2}$ allowed us to reveal several novel features pertaining to the dynamics of the process.

First, HMW chromatin fragmentation is a very rapid process that commences within minutes after the administration of the stressor. The rapidity of chromatin fragmentation in response to $\mathrm{H}_{2} \mathrm{O}_{2}$ strongly indicates that biochemical rather than genetic mechanisms mediate the process. The maximal $>400 \mathrm{~kb}$ ssDNA fragmentation is actually achieved within 10-15 min. Because the loss of cell viability (as measured by trypan blue exclusion) is not evident for up to $45 \mathrm{~min}$, and because the cells mount a very effective DNA "repair" response after the removal of $\mathrm{H}_{2} \mathrm{O}_{2}$, the genomic damage clearly precedes the impairment of other vital cellular functions that ultimately lead to the loss of cellular integrity. Second, only a discrete pool representing approximately half of total nuclear chromatin is digestible. This pool may correspond to transcriptionally active euchromatin as suggested by Hendzel et al (1998) who proposed that HMW DNA degradation during PCD commences at the euchromatic regions relieving structural constraints on the interphase chromosomes, and thus, allowing the heterochromatin to aggregate. Third, cells possess efficient mechanisms to repair both single and double stranded breaks, but only at AT-rich MARs (>400 kb fragmentation). Even when both DNA strands are severed, $>400 \mathrm{~kb}$ fragments apparently retain substantial structural 
integrity within the chromosomes because they are still attached to the matrix by multiple intervening MARs with lower AT content. This structural integrity allows the religation of even dsDNA fragments. On the other hand, bifilar scission at consecutive MARs generating 50-200 kb fragments leads to the liberation of individual chromatin loops. Because the excised loops may be easily translocated within or out of the chromosome, they cannot be religated. Surprisingly, even single stranded breaks were not repaired at these sites. Hence, the 50-200 kb fragmentation represents an irreversible damage that may lead to the truncation and/or loss of genes.

Chromatin fragmentation can be elicited by $\mathrm{H}_{2} \mathrm{O}_{2}$ at concentrations as low as $50 \mu \mathrm{M}$, and concentrations $>500 \mu \mathrm{M}$ produce maximal effect within 15 min. Such $\mathrm{H}_{2} \mathrm{O}_{2}$ concentrations are highly relevant to pathological conditions in vivo. For example, during ischemia/reperfusion of brain tissue, there is a significant rise in $\mathrm{H}_{2} \mathrm{O}_{2}$ levels for about $1 \mathrm{~h}$ reaching up to approximately $175 \mu \mathrm{M}$ (Hyslop et al, 1995). Such prolonged exposure to $\mathrm{H}_{2} \mathrm{O}_{2}$ would certainly be genotoxic to OL. In fact, OL degenerate and die rapidly during and after ischemic insult to the brain (Pantoni et al, 1996, Petito et al, 1998). Even more dramatic increases in $\mathrm{H}_{2} \mathrm{O}_{2}$ levels may occur during inflammatory episodes. For example, millimolar concentrations of $\mathrm{H}_{2} \mathrm{O}_{2}$ were found in mouse brains during the active phase of experimental allergic encephalomyelitis (Scott et al, 1995). Third, we have shown that calcium is required for $\mathrm{H}_{2} \mathrm{O}_{2}$-induced activation of MAR-associated endonuclease as buffering of intracellular calcium with BAPTA/AM totally abrogates chromatin fragmentation (fig.10). However, calcium by itself does not directly activate MAR-associated endonuclease as seen from the lack of chromatin fragmentation in A23187-treated cells (fig.12C), and from the inability of 
calcium to activate or facilitate chromatin digestion in isolated nuclei (fig.17). Furthermore, the depletion of intracellular calcium by the pretreatment of cells with BAPTA/AM profoundly attenuated the activity of endonuclease in isolated nuclei (fig.19). These results strongly indicate calcium-dependent modification of MAR-associated endonuclease through, for example, phosphorylation of the enzyme. Accordingly, at resting concentrations of intracellular calcium, the enzyme exists in a dephosphorylated form that is responsive to the activation by cytoplasmic signals elicited by $\mathrm{H}_{2} \mathrm{O}_{2}$. In the absence of calcium, the enzyme is inactivated by phosphorylation, and becomes unresponsive to the cytoplasmic signals and even to magnesium activation in isolated nuclei. Because the phosphorylation reaction is energy dependent, the enzyme can only be inactivated by calcium depletion in intact cells (fig.10 \& 19), but not in isolated nuclei (fig.20). However, it should also be considered that calcium-dependent modification may involve not only the endonuclease itself, but also other proteins that control the access of the enzyme to the DNA within the MAR complex. Our results do not exclude the possibility that in addition to controlling the activity of endonuclease, calcium has a role in the generation of $\mathrm{H}_{2} \mathrm{O}_{2}$-triggered signaling cascades upstream from the MAR complex. Fourth, our results have demonstrated that the initial step of HOCD, i.e., scission into $\geq 400 \mathrm{~kb}$ ssDNA at AT-rich MARs proceeds through different mechanisms than the subsequent scissions into $\geq 400 \mathrm{~kb}$ dsDNA, 50-300 ssDNA and 50-300 dsDNA fragments. Thus, the initial $\geq 400 \mathrm{~kb}$ ssDNA scission is iron-independent, whereas the subsequent digestion requires iron (fig.11). This iron-dependence may reflect either the presence of at least two endonucleases operating at AT-rich MARs, or a differential activation of MAR-associated endonuclease by specific upstream signals elicited by $\mathrm{H}_{2} \mathrm{O}_{2}$. 
The effect of DFOM on $\geq 400$ dsDNA and 50-300 ssDNA digestion may be related to the decrease in intracellular calcium caused by the chelation of iron as previously shown in $\mathrm{H}_{2} \mathrm{O}_{2}$-treated renal cells (Golconda et al, 1993). Fifth, this study has shed light on the nature of $\geq 400 \mathrm{~kb}$ ssDNA fragments normally present in untreated cells (fig.10, 11, 12B, 12C) and in nuclei isolated from untreated cells (fig.17-20). A substantial amount of these fragments has been observed in other untreated cells as well (Walker et al, 1997). We have shown (Mouzannar et al, 2001) that in oligodendrocytes, these fragments represent approximately $10 \%$ of total chromatin DNA. Although the origin of these fragments has not been fully addressed, it has been postulated that they result from the scission at AT-rich MARs which feature ssDNA and/or secondary DNA structures that are S1 sensitive (Bode et al, 1992). Our demonstration that the $\geq 400 \mathrm{~kb}$ ssDNA fragments can be efficiently eliminated by the pretreatment of cells with BAPTA/AM (fig. $10 \& 19)$ proves that these fragments result from a dynamic equilibrium between scission and ligation at AT-rich MARs, rather than from specific DNA structures. 


\section{CONCLUSION}

Extensive HMW chromatin fragmentation is a very early response of OL to

oxidative stress leading to irreversible genomic damage. This DNA damage may result in somatic mutations, and consequently lead to cellular degeneration, and/or death. The rapidity of chromatin fragmentation in response to $\mathrm{H}_{2} \mathrm{O}_{2}$ strongly indicates that biochemical rather than genetic mechanisms mediate the process. $\mathrm{H}_{2} \mathrm{O}_{2}$-induced OL HOCD can not be attributed to the increase of intracellular calcium, but rather to other signaling molecules triggered by $\mathrm{H}_{2} \mathrm{O}_{2}$ that activate MAR-associated endonuclease. However, resting intracellular calcium is absolutely required to maintain MAR-associated endonuclease in a state responsive to the activation by these signaling molecules. This study has also revealed that individual stages of HOCD may entail specific signaling molecules, and/or specific endonucleases, and that even in naïve cells a sizable fraction of nuclear chromatin contains single stranded breaks at AT-rich MARs. Hence, blocking chromatin fragmentation may prevent the loss of oxidatively compromised OL in human pathologies, such as stroke, traumatic injury, and multiple sclerosis. 


\section{APPENDIX}

\section{A-BUFFERS}

TE

10 mM TRIZMA Base, pH 7.2 adjusted with $\mathrm{HCl}, 1$ mM EDTA.

TBE

0.45 M TRIZMA Base, $0.45 \mathrm{M}$ boric acid, $5 \mathrm{mM}$ EDTA.

S1 nuclease

Storage buffer: $20 \mathrm{mM}$ Tris- $\mathrm{HCl}, 50 \mathrm{mM} \mathrm{NaCl}$,

$0.1 \mathrm{mM} \mathrm{ZnCl}, 50 \%$ (v/v) glycerol.

Incubation buffer: $30 \mathrm{mM}$ sodium acetate $\mathrm{pH}$ 4.6, $100 \mathrm{mM} \mathrm{NaCl}, 0.5 \mathrm{mM} \mathrm{ZnCl}{ }_{2}$.

Agarose protein/lipid extraction $10 \mathrm{mM}$ Tris- $\mathrm{HCl}, \mathrm{pH} 9.5,10 \mathrm{mM} \mathrm{NaCl}, 25 \mathrm{mM}$ EDTA, 1 mM EGTA, 1.5\% SDS, $0.1 \%$ $\beta$-mercaptoethanol.

Agarose embedding 15 mM Tris-HCl, pH 7.4, 1 mM EGTA, 2 mM EDTA, $60 \mathrm{mM} \mathrm{KCl}, 15 \mathrm{mM} \mathrm{NaCl}, 0.5 \mathrm{mM}$ spermidine, $0.15 \mathrm{mM}$ spermine.

Nuclei isolation (NI) $15 \mathrm{mM}$ Tris-HCl, $15 \mathrm{mM} \mathrm{NaCl}, 60 \mathrm{mM} \mathrm{KCl,} 2$ mM EDTA, 1 mM DTT, $0.5 \mathrm{mM}$ spermine, 0.15 mM spermidine, $0.5 \mathrm{mM}$ PMSF, $0.32 \mathrm{M}$ sucrose. Nuclei incubation $10 \mathrm{mM}$ Tris- $\mathrm{HCl} \mathrm{pH}$ 7.5, 15 mM NaCl, $60 \mathrm{mM}$ $\mathrm{KCl}, 0.32 \mathrm{M}$ sucrose. 


\section{B-CULTURE MEDIA}

Medium A: Hank's balanced salt solution (HBSS) (GibcoBRL, Hepes, $\mathrm{Ca}^{2+}$ and $\mathrm{Mg}^{2+}$ - free, phenol red; \# 21250-014), 0.05\% acetylated trypsin (Sigma \# T6763), 1\% antibiotics-antimycotics (Sigma \# A5955), pH 7.2.

Medium B: $1 \mathrm{mg} / \mathrm{ml}$ DNaseI (Sigma \# D5025) solubilized in medium A.

Medium C medium A with 10\% fetal calf serum (FCS) (Gibco, Grand Island, NY; 16000-044).

Medium D DMEM-F12 (Gibco, Grand Island, NY; \# 12400-024), 1.2 g NaHCO $_{3}$ (Sigma \# S5761), 1\% antibiotics-antimycotics, pH 7.2.

Medium E medium D with 10\% FCS.

Oligodendrocyte Enhancing Medium (OEM)

Medium D containing $5 \mu \mathrm{g} / \mathrm{ml}$ insulin (Sigma \# I6634), $50 \mu \mathrm{g} / \mathrm{ml}$ holotransferrin (Sigma \# T1283) $30 \mathrm{nM}$ sodium selenite (Sigma \# S5261), $30 \mathrm{nM}$ Triiodothyronine (Sigma \# T6397), $1 \mathrm{mg} / \mathrm{ml}$ bovine serum albumin (Sigma \#), 10 ng/ml d-Biotin (Sigma \# B4639), $20 \mathrm{nM}$ progesterone (Sigma \# P8783), $100 \mu \mathrm{M}$ putrescine (Sigma \# P5780), 4.85 mg/ml D-glucose (Sigma \# G7021), 0.5\% FCS. Trypsin-EDTA solution (Sigma, \# T3924)

\section{C-ABBREVIATIONS}

ADP: Adenosine 5'-Diphosphate

ATP: Adenine 5'-TriPhosphate

CNS: Central Nervous System 
DFOM: DeFerrOxamine Methylate

DMSO: DiMethyl SulfOxide

dsDNA: Double Strand DNA

EDTA: EthyleneDiamine TetraAcetate

FIGE: Field Inversion Gel Electrophoresis

GSH: Glutathione (reduced)

GSSG: Glutathione (oxidized)

HBSS: Hank's Buffered Salt Solution

HOCD: Higher Order Chromatin Digestion/Degradation

HMG: High Mobility Group proteins

HMW: High Molecular Weight

MAR: Matrix Attachment Region

NADPH: Nicotinamide Adenine Dinucleotide (reduced)

OEM: Oligodendrocyte Enhancing Medium

OL: Oligodendrocyte

OS: Oxidative Stress

PARP: Poly-(ADP-Ribose) Polymerase

PCD: Programmed Cell Death

ROS: Reactive Oxygen Species

SOD: SuperOxide Dismutase

ssDNA: Single Strand DNA 


\section{REFERENCES}

Alexander M, Newmark H, Miller RG (1985) Oral beta-carotene can increase the number of OKT4+ cells in human blood. Immunol Lett 9:221-224.

Allan J, Hartman PG, Crane-Robinson C, Aviles FX (1980) The structure of histone H1 and its location in chromatin. Nature 288:675-679.

An W, Leuba SH, van Holde K, Zlatanova J (1998a) Linker histone protects linker DNA on only one side of the core particle and in a sequence dependent manner. Proc Natl Acad Sci USA 95:3396-3401.

An W, van Holde K, Zlatanova J (1998b) The non-histone chromatin protein HMG1 protects linker DNA on the side opposite to that protected by linker histones. J Biol Chem 273:26289-26291.

Anderson R, Lukey PT (1987) A biological role for ascorbate in the selective neutralization of extracellular phagocyte-derived oxidants. Annals of New York Academy of Sciences 498:229-233.

Anzai N, Kawabata H, Hiram T, Masutani H, Ueda Y, Okuma M (1995) Types of endonuclease activity capable of inducing internucleosomal DNA 
fragmentation are completely different between human CD34(+) cells and their granulocytic descendants. Blood 86:917-23.

Bartholdi D, Schwab ME (1995) Methylprednisolone inhibits early inflammatory processes but not ischemic cell death after experimental spinal cord lesion in the rat. Brain Res. 672:177-186.

Beck MA (1997) Rapid genomic evolution of a non-virulent coxsackievirus B3 in selenium-deficient mice. Biomed Environ Sci 10:307-315.

Beck MA (1997) Increased virulence of coxsackievirus B3 in mice due to vitamin E or selenium deficiency. J Nutr 127:966S-970S.

Bednar J, Horowitz RA, Grigoryev SA, Carruthers LM, Hansen JC, Koster AJ, Woodcock CL (1998) Nucleosomes, linker DNA, and linker histone form a unique structural motif that directs the higher-order folding and compaction of chromatin. Proc Natl Acad Sci USA 95:14173-14178.

Beere, HM, Chresta, CM, Alejo-Herberg, A, Skladanowski, A, Dive, C, Larsen, AK, Hickman, JA (1995) Investigation of the mechanism of higher order chromatin fragmentation observed in drug-induced apoptosis. Molecular Pharmacology 47:986-996. 
Benda P, Lightbody J, Sato G.H, Levine L, Sweet H (1968) Differentiated rat glia cell strain in tissue culture. Science 161:370-371.

Benjamins, JA., Nedelkoska, L (1996) Release of intracellular calcium stores leads to retraction of membrane sheets and cell death in mature mouse oligodendrocytes. Neurochem Res 21:471-479.

Benveniste EN (1997) Role of macrophages/microglia in muyltiple sclerosis and experimental allergic encephalomyelitis. J Mol Med 75:165-173.

Ben-Yoseph O, Boxer PA, Ross BD (1994) Oxidative stress in the central nervous system: monitoring the metabolic response using the pentose phosphate pathway. Dev Neurosci 16:328-336.

Bissell M.G, Rubenstein L.J, Bignami A, Herman M.M (1974) Characteristics of the rat C6 glioma maintained in organ culture system. Production of glial fibrillary acidic protein in the absence of gliofibrillogenesis. Brain Res 82:77-89.

Blisard KS, Follis F, Wong R, Miller KB, Wernly JA, Scremin OU (1995) Degeneration of axons in the corticospinal tract secondary to spinal cord ischemia in rats. Paraplegia 33:136-140. 
Bode J, Kohwi Y, Dickinson L, Joh T, Klehr D, Mielke C, Kohwi-Shigematsu T (1992) Biological significance of unwinding capability of nuclear matrixassociated DNAs. Science 255:195-197.

Boles, TC, Hogan, ME (1987) DNA structure equilibria in the human c-myc gene. Biochem 26:367-376.

Brown, DG, Sun, XM, Cohen, GM (1993) Dexamethasone-induced apoptosis involves cleavage of DNA to large fragments prior to internucleosomal fragmentation. J Biol Chem 268:3037-3039.

Bustin M, Reeves R (1996) High-mobility-group chromosomal proteins: architectural components that facilitate chromatin function. Prog. Nucleic Acid Res. Mol. Biol. 54:35-100.

Carle GF, Frank M, Olson MV (1986) Electrophoretic separation of large DNA molecules by periodic inversion of the electric field. Science 232:65-68.

Casciola-Rosen, L, Nicholson, DW, Chang, T, Rowan, KR, Thomberry, NA, Miller, DK, Rosen, A (1996) Apopain/CPP32 cleaves proteins that are essential for cellular repair: A fundamental principle of apoptotic death. Journal of Experimental Medicine 183:1957-1964. 
Chan YL, Olvera J, Wool IG (1983) The structure of a rat 28S ribosomal ribonucleic acid inferred from the sequence of nucleotides in a gene. Nucleic Acid Res. 11:7819-7831.

Chia LS, Thompson JE, Moscarello MA (1983) Disorder in human myelin induced by superoxide radical: an in vitro investigation. Biochem Biophys Res Commun 117:141-146.

Chinnayian AM, Tepper CG, Seldin MF, O'Rourke K, Kischkel FC, Helbard S, Krammer PH, Peter M.E., Dixit VM (1996) FADD/MORT1 is a common mediator of CD95 (Fas/APO1) and tumor necrosis factor receptor-induced apoptosis. J Biol Chem 271:4961-4965.

Cohen GM, Sun XM, Fearnhea H, MacFarlane M, Brown DG, Snowden RT, Dinsdale D (1994) Formation of large molecular weight fragments of DNA is a key committed step of apoptosis in thymocytes. J Immun 153:507-516.

Colussi PA, Kumar S (1999) Targeted disruption of caspase genes in mice: what they tell us about the functions of individual caspases in apoptosis. Immuno Cell Biol 77:58-63.

Comings DE In de Lachapelle A, Sorsa M (1977) (eds) Chromosomes Today. Elsevier/North-Holland, Amsterdam. Vol. 6 pp. 19-26. 
Connor JR (1994) Iron acquisition and expression of iron regulatory proteins in the developing brain: manipulation by ethanol exposure, iron deprivation and cellular dysfunction. Dev Neurosci 16:233-247.

Davies KJ (2000) Oxidative stress, antioxidant defenses, and damage removal, repair, and replacement systems. IUBMB Life 50:279-289.

Deby C, Goutier R (1990) New perspective on the biochemistry of superoxide anion and the efficiency of superoxide dismutases. Biochem Pharmac 39:399-405.

Demediuk P, Faden AI (1988) Traumatic spinal cord injury in rats causes increases in tissue thromboxane but not peptidoleukotriens. J Neurosci Res. 20:115-121.

Dickinson LA, Joh T, KohwiY, Kohwi-Shigematsu T (1992) A tissue-specific MAR/SAR DNA-binding protein with unusual binding site recognition. Cell 70:631-645.

Duvall E, Willie AH (1986) Life and death of the cell. Immunol Today 7:115-119.

Earnshaw WC (1995) Nuclear changes in apoptosis. Curr Opin Cell Biol 7:337-343. 
Filipski J, Leblanc J, Youdale T, Sikorska M. Walker P.R (1990) Periodicity of DNA folding in higher order chromatin structures. EMBO J 9:1319-1327.

Fimia GM, Gottifredi V, Passananti C, Maione R (1996) Double-stranded internucleosomal cleavage of apoptotic DNA is dependent on the degree of differentiation in muscle cells. J Biol Chem 271:15575-79.

Finch, JT, Lutter, LC, Rhodes, D, Brown, RS, Rushton, B, Levitt, M, Klug, A (1977) Structure of nucleosomes core particles of chromatin. Nature 269:29-36.

Frimer AA, Forman A, Borg DC (1984) $\mathrm{H}_{2} \mathrm{O}_{2}$-diffusion through liposomes. Israel J Chem 23:442-445.

Garcia-Martinez V, Macias D, Ganan Y, Garcia-Lobo JM, Francia MV, Fernandezteran MA, Hurle JM (1993) Internucleosomal DNA fragmentation and programmed cell death (apoptosis) in the interdigital tissue of the embryonic chick leg bud. J Cell Sci 106:201-208.

Golconda, MS, Ueda, N, Shah, SV (1993) Evidence suggesting that iron and calcium are interrelated in oxidant-induced DNA damage. Kidney Int 44:1228-1234.

Goldstein (1997) Controlling cell death. Science 275:1081-1082 
Griot C, Vandevelde M, Richard A, Peterhans E, Stocker R (1990) Selective degeneration of oligodendrocytes mediated by reactive oxygen species. Free Rad Res Comms 11:181-193.

Greidinger, EL, Miller, DK, Yamin, TT, Casciola-Rosen, L, Rosen, A (1996) Sequential activation of three distinct ICE-like activities in Fas-ligated Jurkat cells. FEBS Letters 390:299-303.

Grubinska B, Laszkiewicz I, Royland JE, Wiggins RC, Konat GW (1994) Differentiation-specific demethylation of myelin associated glycoprotein gene in cultured oligodendrocytes. J Neurosc Res 39:233-242.

Gu, J, Royland, JE, Wiggins, RC, Konat, GW (1997) Selenium is required for normal upregulation of myelin genes in differentiating oligodendrocytes. J Neuro Res 47:626-635.

Haber F, Weiss J (1934) The catalytic decomposition of hydrogen peroxide by iron salts. Proc Roy Soc London (A) 147:332-342.

Halliwell B, Gutteridge JM (1989) Free Radicals in Biology and Medicine. Clarendon Press, Oxford. 
Hara SS, Halicka HD, Bruno S, Gong JP, Traganos F, Darzynkiewicz Z (1996) Effect of protease inhibitors on early events of apoptosis. Exp Cell Res 223:372-84.

Harman D (1994) Free radical theory of aging: Increasing the functional life span. Ann NY Acad Sci 717:1-15.

Hendzel, MJ, Nishioka, K, Raymond, Y, Allis, CD, Bazett-Jones, DP, Th'ng, PH (1998) Chromatin condensation is not associated with apoptosis. J Biol Chem 273:24470-24478.

Hermann M, Voll R, Woith W, Hagenhofer M, Lorenz HM, Manger B, Kalden JR (1996) Small DNA fragments isolated from human T-cell clones are enriched in sequences involved in DNA bending. Cell Death Differentiation 3:391-95.

Hewish, D, Burgoyne, L (1973) Chromatin sub-structure: the digestion of chromatin DNA at regularly spaced sites by a nuclear deoxyribonuclease. Biochemical and Biophysical Research Communications 52: 504-10.

Hooper DC, Bagasra O, Marini JC, Zborek A, Ohnishi ST, Kean R, Champion JM, Sarker B, Bobroski L, Farber JL, Akaike T, Meada H, Koprowski H (1997) Prevention of experimental allergic encephaslomyelitis by targeting nitric oxide and peroxynitrite: implications for the treatment of multiple sclerosis. Proc Natl Acad Sci USA 94:2528-2533. 
Hooper DC, Spitsin S, Kean RB, Champion JM, Dickson GM, Chaudhry I, Koprowski H (1998) Uric acid, a natural scavanger of peroxynitrite, in experimental allergic encephalomyelitis and multiple sclerosis. Proc Natl Acad Sci USA 95:675-680.

Husain J, Juurlink BHJ (1995) Oligodendroglial precursor cell susceptibility to hypoxia is related to poor ability to cope with reactive oxygen species. Brain Res 698:86-94.

Hyslop PA, Hinshaw DB, Schraufstatter IU, Sklar LA, Spragg RG, Cochrane CG (1986) Intracellular calcium homeostasis during hydrogen peroxide injury to cultured P388D ${ }_{1}$ cells. J Cell Physiol 129:356-366.

Hyslop, PA, Zhang, Z, Pearson, DV, Phebus, LA, (1995) Measurement of striatal $\mathrm{H}_{2} \mathrm{O}_{2}$ by microdialysis following global forebrain ischemioa and reperfusion in the rat: correlation with the cytotoxic potential of $\mathrm{H}_{2} \mathrm{O}_{2}$ in vitro. Brain Res 671:181-186.

Jain A, Martensson J, Stole E, Auld PA, Meister A (1991) Glutathione deficiency leads to mitochondrial damage in brain. Proc Natl Acad Sci USA 88:19131917. 
Jimenez-Jimenez FJ, Molina JA, de Bustos F, Orti-Pareja M, benito-Leon J, TallonBarranco A, Gasalla T, Porta J, Arenas J (1999) Serum levels of betacarotene, alpha-carotene and vitamin A in patients with Alzheimer's diesease. Eur J neurol 6:495-497.

Jones DP, McConkey DJ, Nicotera P, Orrenius S (1989): Calcium-activated DNA fragmentation in rat liver nuclei. J Biol Chem. 264:6398-6403.

Josephson RA, Silverman HS, Lakatta EG, Stern MD, Zweier JL (1991) Study of the mechanisms of hydrogen peroxide and hydroxyl free radical-induced cellular injury and calcium overload in cardiac myocytes. J Biol Chem 266:2354-2361.

Juurlink BHJ (1997) Response of glial cells to ischemia: Roles of reactive oxygen species and glutathione. Neurposci Behavioral Rev 21:151-166.

Juurlink BH, Hertz L (1993) Ischemia-induced death of astrocytes and neurons in primary culture: pitfalls in quantifying neuronal cell death. Dev Brain Res 71:239-246.

Kaim W, Schwederski B (1994) Catalysis and regulation of bioenergetic processes by the alkaline earth metal ions $\mathrm{Mg} 2+$ and $\mathrm{Ca} 2+$. In: Bioinorg Chem: Inorg elements in the chemnistry of life, eds W. Waim \& B Schwewderski, pp 286302. Chichester: J Wiley and Sons. 
Katiyar SK, Mukhtar H (2001) Green tea polyphenol (-)-epigallocatechin-3-gallate treatment to mouse skin prevents UVB-induced infiltration of leukocytes, depletion of antigen-presenting cells, and oxidative stress. J Leukoc Biol 69:719-726.

Kawabata H, Anzai, N, Ueda Y, Masutani H, Hirama T, Yoshida Y, Okuma M (1996) High levels of $\mathrm{Ca}^{2+}$-independent endonuclease activity capable of producing nucleosomal-size DNA fragmentation in non-adherent marrow mononuclear cells from patients with myelodysplastic syndromes and acute myelogenous leukemia. Leukemia 10:67-73.

Kawabata H, Anzai, N, Masutani H, Hirama T, Yoshida Y, Okuma M (1993) Detection of Mg2+-dependent endonuclease activity in myeloid leukemia cell nuclei capable of producing internucleosomal DNA cleavage. Biochem Biophys Res Commun 191:247-254.

Kerr JFR, Wyllie AH, Currie AR (1972) Apoptosis: A basis biological phenomenon with wide-ranging implications in tissue kinetics. Br J Cancer 26:239-57.

Khodarev NN, Sokolova IA, Vaughan ATM (1998) Mechanisms of induction of apoptotic DNA framgentation. Int J Radiat Biol 73:455-467. 
Kim YS, Kim SU (1991) Oligodendroglial cell death induced by oxygen radicals and its protection by catalase. J Neurosci Res 29:100-106.

Konat G, Gantt G, Gorman A. \& Wiggins RC (1986) Peroxidative aggregation of myelin membrane proteins. Metab.Brain Disease 1:177-185.

Konat G, Gantt G, Laszkiewicz I \& Hogan EL (1990) Rapid isolation of genomic DNA from animal tissues. Exp.Cell Res. 190:294-296.

Konat G, Laszkiewicz I, Bednarczuk T, Kanoh M, Wiggins RC (1991): Generation of radioactive and nonradioactive ssDNA hybridization probes by polymerase chain reaction. Technique 3:64-68.

Konat GW, Wiggins RC (1985) Effect of reactive oxygen species on myelin membrane proteins. J Neurochem 45:1113-1118.

Kornberg RD, Thomas JO (1974) Chromatin structure: oligomers of the histones. Science 184:865-8.

Kornberg RD (1974) Chromatin structure: a repeating unit of histones and DNA. Science 184:868-71. 
Kritchevsky SB (1999) beta-carotene, carotenoids and the prevention of coronary heart diusease. J Nutr 129:5-8.

Lagarkova MA, Iarovaia OV, Razin SV (1995) Large scale fragmentation of mammalian DNA in the course of apoptosis procedes via excision of chromosomal DNA loops and their oligomers. J Biol Chem 270:20239-20245.

Laskey RA, Mills AD, Morris NR (1997) Assembly of SV40 chromatin in a cell-free system from Xenopus eggs. Cell 10:237-43.

Laszkiewicz I, Mouzannar R, Wiggins RC, Konat GW (1999) Delayed oligodendrocyte degeneration induced by brief exposure to hydrogen peroxide. Journal of Neuroscience Research 55: 303-310.

Leuba SH, Bustamante C, van Holde K, Zlatanova J (1998) Linker histone tails and the $\mathrm{N}$-tails of histone $\mathrm{H} 3$ are redundant: scanning force microscopy studies of reconstituted fibers. Biophys J 74:2830-2839.

LeVine SM, Macklin WB (1990) Iron-enriched oligodendrocytes: a reaxamination of their spatial distribution. J Neurosci Res 26:508-512. 
Liu X, Kim NC, Yang J, Jemmerson R, Wanf X (1996) Induction of apoptotic program in cell free extract: requirement for dATP and cytochrome C. Cell $86: 147-157$.

Liu QY, Padney S, Singh RK, Lin W, Ribecco M, Borowy-Borowski H, Smith B, LeBlanc J, Walker PR, Sikorska M (1998) DNaseY: A rat DNase-like gene coding for a constitutively expressed chromatin-bound endonuclease. Biochemistry 37:10134-10143.

Lockshin RA, Zakeri Z, Tilly JL (Ed.) When Cells Die. A Comprehensive Evaluation of Apoptosis and Programmed Cell Death. Wiley-Liss, New York, Chichester, Weinheim, Brisbane, Singapore, Toronto, pp 211-242.

Love S (1999) Oxidative stress in brain ischemia. Brain Pathol 9:119-131.

Lutter, LC (1978) Kinetic analysis of deoxyribonuclease I cleavages in the nucleosome core: evidence for a DNA superhelix. J Mol Biol 124:391-420.

Maru Y (2001) Molecular biology of chronic myeloid leukemia. Int J Hematol. 73:308-322.

McCarthy KD, de Vellis J (1980) Preparation of separate astroglial and oligodendroglial cell cultures from rat cerebral tissue. J Cell Biol 85:890-902. 
McConkey DJ, Hartzell P, Amador-Perez JF, Orrenius S (1989) Calcium-activated DNA fragmentation kills immature thymocytes. FASEB J 3:1843-49.

Mehta RC, Pike GB, Enzmann DR (1996) Measure of magnetization transfer in multiple sclerosis demyelinating plaques, white matter ischemic lesions, and edema. Am J Neuroradiol 17:1051-1055.

Messam CA, Pittman RN (1998) Asynchromy and commitment to die during apoptosis. Exp Cell Res 238:389-398.

Milner RJ, Lai C, Nave K-A, Lenoir D, Ogata J, Sutcliffe JG (1985) Nucleotide sequences of two mRNAs for rat brain myelin proteolipid protein. Cell 42:931-939.

Mitrovic B, Ignarro LJ, Vinters HV, Akers MA, Schmid I, Uittenbogaart C, Merrill JE (1995) Nitric oxide induces necrotic but not apoptotic cell death in oligodendrocytes. Neuroscience 65:531-539.

Moir RD, Spann TP, Goldman RD (1995) The dynamic properties and possible functions of nuclear lamins. Int Rev Cytol 162B:141-182. 
Mouzannar R, Laszkiewicz, I, Wiggins, RC, Konat, GW (1999) Chromatin fragmentation in oxidatively stressed oligodendrocytes. J Neurochem 72:S6D.

Mouzannar R, Miric, SJ, Wiggins, RC, Konat, GW, (2001) Hydrogen peroxide induces rapid digestion of oligodendrocyte chromatin into high molecular weight fragments. Neurochem Int 38:9-15.

Newman S, Kitamura K, Campagnoni AT (1987): Identification of a cDNA coding for a fifth form of myelin basic protein in mouse. Proc. Natl. Acad. Sci. USA 84:886-890.

Nickol, JM, Felsenfeld, G, (1983) DNA conformation at the 5' end of the chicken adult beta-globin gene. Cell 35:467-477.

Noble PG, Antel JP, Young VW (1994) Astrocytes and catalase prevent the toxicity of catecholamines to oligodendrocytes. Brain Res 633:83-90.

Oberhammer, F, Fritsch, G, Schmeid, M, Pavelka, M, Printz, D., Purchio, T, Lassmann, H, Schulte-Hermann, R, (1993a). Condensation of the chromatin at the membrane of an apoptotic nucleus is not associated with activation of activation of an endonuclease. J Cell Sci 104:317-326. 
Oberhammer, F, Wilson, JW, Dive, C, Morris, ID, Hickman, JA, Wakeling, AE, Walker, PR, Sikorska, M, (1993b). Apoptotic death in epithelial cells: cleavage of DNA to 300 and /or $50 \mathrm{~kb}$ fragments prior to or in the absence of internucleosomal fragmentation. EMBO 12:3679-3684.

Ohkochi N, Endoh T, Oikawa K, Seya K, Satomi S (1999) Fragility of the electron transport chain and superoxide generation in mitochondria of the liver graft after cold ischemia. Transplantation 67:1173-1177.

Olins, AL, Olins, DE (1974) Spheroid chromatin units ( $v$ bodies). Science 183:330-1.

Oppenheimer SM, Bryan RN, Conturo TE, Soher BJ, Preziosi TJ, Barker PB (1995) Proton magnetic resonance spectroscopy and gadolinium-DTPA perfusion imaging of asymptotic MRI white matter lesions. Magn Reson Med 33:61-68.

Oren A, Taylor JM (1995) The subcellular localization of defensins and myeloperoxidase in human neutrophils: immunocytochemical evidence for azurophil granule heterogeneity. J Lab Clin Med 125:340-347.

Pandey, S, Walker, PR, Sikorska, M (1994) Separate pools of endonuclease activity are responsible for internucleosomal and high molecular mass DNA fragmentation during apoptosis. Biochem Cell Biol 72:625-629. 
Pantoni, L, Garcia, JH, Gutierrez, JA (1996) Cerebral white matter is highly vulnerable to ischemia. Stroke 27:1641-1646.

Peitsch, MC, Muller, C, Tschopp, J (1993) DNA fragmentation during apoptosis is caused by single-strand cuts. Nucleic Acid Res 21:4206-4209.

Persoon-Rothert M, Egas-Kenniphaas JM, van der Valk-Kokshoorn EJ, Buys JP, van der Laarse A (1994) Oxidative stress-induced perturbations of calcium homeostasis and cell death in cultured myocytes: role of extracellular calcium. Mol Cell Biochem 6:1-9.

Petito, CK, Orlate, JP, Roberts, B, Nowak, TS, Pulsinelli, WA (1998) Selective glial vulnerability following transient global ischemia in rat brain. Journal of Neuropath Exp Neurol 57:231-238.

Pfeiffer S.E, Herschman HR, Lightbody J, Sato G, (1970) Synthesis by a clonal line of rat glial cells of proteins unique to the nervous system. J Cell Physiol 75:329-340.

Piper P (1997) The yeast heat shock response. In: Yeast stress responses, eds S Hohmann \& W.H. Mager, pp. 75-99, New York: Springer. 
Rao L, Perez D, White E (1996) Lamin proteolysis facilitates nuclear events during apoptosis. Journal of cell Biology 135:1441-1455.

Reed CJ (2000) Apoptosis and cancer: strategies for integrating programmed cell death. Semin Hematol 37:9-16.

Reynolds, WF, Gottesfeld, JM, (1985) Torsional stress induces an S1 nucleasehypersensitive site within the promoter of the Xenopus laevis oocyte-type 5S RNA gene. Proceedings of National Academy of Science USA 82:4018-4022.

Richmond, TJ, Finch, JT, Rushton, B, Rhodes, D, Klug, A (1984) Structure of the nucleosome core particle at $7 \AA$ resolution. Nature 311:532-7.

Ruiz-Carrillo, A (1984) The histone H5 gene is flanked by S1 hypersensitive structures. Nucleic Acid Research 12:6473-6492.

Sato T, Irie S, Krajewski S, Reed JC (1994) Cloning and sequencing of a cDNA encoding the rat Bcl-2 protein. Gene 140:291-292.

Schmidt K (1991) Antioxidant vitamins and beta-carotene; Effects on immunocompetence. Am J Clin Nut 53:383S-385S. 
Schreck R, Albermann K, Baeuerle PA (1992) Nuclear factor kB: an oxidative stressresponsive transcription factor of eukaryotic cells. Free Rad Res Commun 17:221-237.

Schwartz DC, Cantor CR (1984) Seperation of yeast chromosome-sized DBAs by pulse field gradient gel electrophoresis. Cell 37:67-74.

Scott, GS, Williams, KI, Bolton, C, (1997) Reactive oxygen species in experimental allergic encephalomyelitis. Biochem Soc Trans 25:166S.

Selvakumaran M, Lin HK, Miyashita T (1994) Immediate early up-regulation of bax expression by $\mathrm{p} 53$ but not TGF beta 1: a paradigm for distinct apoptotic pathways. Oncogene 9:1791-1798.

Sikorska, M, Walker, PR (1998) Endonuclease activities and apoptosis. In: Lockshin, R.A., Zakeri, Z., Tilly, J.L. (Ed.) When Cells Die. A Comprehensive Evaluation of Apoptosis and Programmed Cell Death. Wiley-Liss, New York, Chichester, Weinheim, Brisbane, Singapore, Toronto, pp 211-242.

Skalka M, Matyasova J, Cejkova M (1976): DNA in chromatin of irradiated lymphoid tissues degrades in vivo into regular fragments. Biochem Biophys Res Commun 72:271-74. 
Slater TF (1984) Free-radical mechanisms in tissue injury. J Biochem 222:1-15.

Spitsin SV, Scott GS, Kean RB, Mikheeva T, Hooper DC (2000) Protection of myelin basic protein immunized mice from free-radical mediated inflammatory cell invasion of the central nervous system by the natural peroxynitrite scavenger uric acid. Neurosci Lett 292:137-141.

Sun, XM, Cohen, GM (1994) $\mathrm{Mg}^{2+}$-dependent cleavage of DNA into kilobase pair fragments is responsible for the initial degradation of DNA in apoptosis. J Biol Chem 269:14857-14860.

Sun, XM, Snowden, RT, Dinsdale, D, Ormerod, MG, Cohen, GM (1993) Changes in nuclear chromatin precede internucleosomal DNA cleavage in the induction of apoptosis by etoposide. Biochem Pharm 2, pp187-195.

Sutcliffe JG, Milner RJ, Shinnick TM, Bloom FE (1983): Identifying the protein product of brain specific genes with antibodies to chemically synthesized peptides. Cell 33:671-682.

Svennerholm L, Vanier M-T, Jungbjer B (1978) Changes in fatty acid composition of human brain myelin lipids during maturation. J Neurochem 30:1383-1390. 
Syburra C, Passi S (1999) Oxidative stress in patients with multiple sclerosis. Ukr Biokhim Zh 71:112-115.

Tator CH, Koyanagi I (1997) Vascular mechanisms in the pathophysiology of human spinal cord injury. J Neurosurg 86:483-492.

Thoma F, Koller T, Klug A (1979) Involvement of histone H1 in the organization of the nucleosome and of the salt-dependent super-structures of chromatin. J Cell Biol 83:403-427.

Thorburn SK, Juurlink BHJ (1996) Low glutathione and high iron govern the susceptibility of oligodendroglial precursors to oxidative stress. J Neurochem 67:1014-1022.

Tosic M, Torch S, Comte V, Dolivo M, Honegger P, Mathieu J-M (1992) Triiodothyronine has diverse and multiple stimulating effects on expression of the major myelin protein genes. J Neurochem 59:1770-1777.

Tretter L, Adam-Vizi V (2000) Inhibition of Krebs cycle enzymes by hydrogen peroxide: A key role of [alpha]-ketoglutarate dehydrogenase in limiting NADH production under oxidative stress. J Neurosci 20:8972-8979. 
Ueda N, Shah SV (1992) Role of intracellular calcium in hydrogen peroxide-induced renal tubular cell injury. Am J Physiol 263:F214-221.

Volpe J.J, Fujimoto K, Marasa J.C, Agrawal H.C (1975) Relation of C6 glial cells in culture to myelin. Biochem J 152:701-703.

Walker GM (19980 magnesium as a stress-protectant for industrial strains of Saccharomyces cerevisiae. J Am Soc Brew Chem 56:109-113.

Walker, PR, LeBlanc, J, Carson, C, Sikorska, M (2000). Neither caspase-3 nor DNA fragmentation factor are required for high molecular weight DNA degradation in apoptosis. Ann New York Acad Sci 887:48-60.

Walker, PR, LeBlanc, J, Sikorska, M (1997) Evidence that DNA fragmentation in apoptosis is initiated and propagated by single-strand breaks. Cell Death and Differentiation 4:506-515.

Walker, PR, Pandey, S, Sikorska, M (1995) Degradation of chromatin in apoptotic cells. Cell Death and Differentiation 2:97-104.

Walker, PR, Sikorska, M (1997) New aspects of the mechanisms of DNA fragmentation in apoptosis. Biochem Cell Biol 75:287-299. 
Wang, JNC, Hogan, M, (1985) An equilibrium between distorted and undistorted DNA in the adult chicken beta A-globin gene. J Biol Chem 260:8194-8202.

Weaver, VM, Carson, CE, Walker, PR, Chaly, N, Lach, B, Raymond, Y, Sikorska, M (1996) Degradation of nuclear matrix and DNA cleavage in apoptotic thymocytes. J Cell Sci 109:45-56.

Whitacre CM, Hashimoto H, Tsai ML, Chatterjee S, berger SJ, Berger NA (1995) Involvment of NAD-poly(ADP-ribose) metabolism in p53 regulation and its consequences. Cancer Res 55:3697-3701.

Williams JR, Little JB, Shipley WU (1974) Association of mammalian cell death with a specific endonucleolytic degradation of DNA. Nature 252:754-56.

Williams RJP (1970) The biochemistry of sodium, potassium, magnesium and calcium. Q Rev Chem Soc 24:331-365.

Williamson R (1970) Properties of rapidly labelled deoxyribonucleic acid fragments isolated from the cytoplasm of primary cultures of embryonic mouse liver cells. J Mol Biol 51:157-68. 
Xu J, Hsu CY, Liu TH, Hogan EL, Perot PL, Tal HH (1990) Leukotriene $B_{4}$ release and polymorphonuclear cell infiltration in spinal cord injury. J Neurochem 55:907-912.

Ye P, Kanoh M, Zhu W, Laszkiewicz I, Royland JE, Wiggins RC, Konat G (1992) Cyclic AMP-induced upregulation of proteolipid protein and myelin associated glycoprotein gene expression in rat glioma C6 cells. J Neurosci Res 31:578-583.

Ye P, Laszkiewicz I Wiggins RC, Konat GW (1994) Transcriptional regulation of myelin associated glycoprotein gene expression by cyclic AMP. J Neurosci Res 37:683-690.

Yim C-Y, Hibbs JB, McGregor JR (1994) Use of N-acetyl cysteine to increase intracellular glutathione during the induction of antitumor responses by IL-2. J Immunol 152:5796-2805.

Yoshida A, Ueda T, Takauji R, Liu Y-P, Fukushima T, Inuzuka M, Nakamura T (1993) Role of calcium ion in induction of apoptosis by etoposide in human leukemia HL-60 cells. Biochem Biophys Res Commun 196:927-34. 
Zhang Z, Guth L (1997) Experimental spinal cord injury: Wallerian degeneration in the dorsal column is followed by revascularization, glial proliferation, and nerve regeneration. Exp. Neurol. 147:159-171.

Zhivotovsky, B, Cederall, B, Jiang, S, Nicotera, P, Orrenius, S (1994) Involvement of $\mathrm{Ca} 2+$ in the formation of high molecular weight DNA fragments in thymocyte apoptosis. Biochem Biophys Res Comm 202:120-127.

Zlatanova J, Leuba SH, van Holde K (1998) Chromatin fiber structure: morphology, molecular determinants, structural transitions. Biophys. J 74:2554-2566.

Zlatanova J, van Holde K (1998) Linker histones versus HMG1/2: a struggle for dominance? Bioessays 20:584-588. 